INTER NATIONAL MONETARY FUND

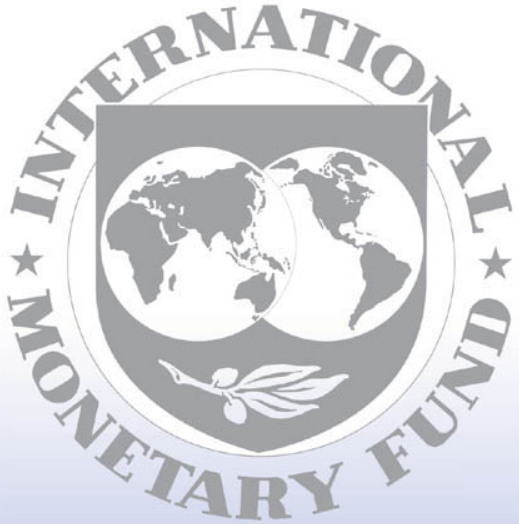

Staff

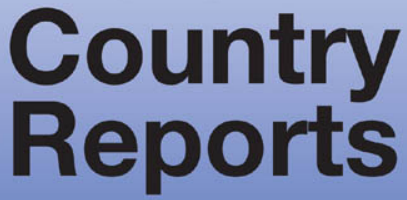




\section{Uganda: Fifth Review Under the Policy Support Instrument and Request for Modification of Assessment Criteria-Staff Report; and Press Release}

In the context of the fifth review under the Policy Support Instrument and request for modification of assessment criteria for Uganda, the following documents have been released and are included in this package:

- $\quad$ The staff report for the Fifth Review Under the Policy Support Instrument and Request for Modification of Assessment Criteria, prepared by a staff team of the IMF, following discussions that ended on April 7, 2009, with the officials of Uganda on economic developments and policies. Based on information available at the time of these discussions, the staff report was completed on May 13, 2009. The views expressed in the staff report are those of the staff team and do not necessarily reflect the views of the Executive Board of the IMF.

- $\quad$ A Press Release summarizing the views of the Executive Board.

The documents listed below have been or will be separately released.

Letter of Intent sent to the IMF by the authorities of Uganda*

Memorandum of Economic and Financial Policies by the authorities of Uganda*

Technical Memorandum of Understanding*

*Also included in Staff Report

The policy of publication of staff reports and other documents allows for the deletion of market-sensitive information.

Copies of this report are available to the public from

International Monetary Fund $\bullet$ Publication Services

$70019^{\text {th }}$ Street, N.W. • Washington, D.C. 20431

Telephone: (202) 623-7430 • Telefax: (202) 623-7201

E-mail: publications@imf.org • Internet: http://www.imf.org

\section{International Monetary Fund \\ Washington, D.C.}


This page intentionally left blank

CInternational Monetary Fund. Not for Redistribution 


\section{UGANDA}

\section{Staff Report for the Fifth Review under the Policy Support Instrument and Request for Modification of Assessment Criteria}

Prepared by the African Department

(In consultation with other departments)

Approved by Saul Lizondo and Dominique Desruelle

May 13, 2009

- $\quad$ Fund relations. The Executive Board approved a three-year Policy Support Instrument (PSI) on December 15, 2006. Outstanding Fund credit amounts to SDR6 million (3.32 percent of quota).

- $\quad$ Staff team. Martine Guerguil (head), Stella Kaendera (both AFR), Manrique Saenz (SPR), Davina Jacobs (FAD) and Chris Papageorgiou (RES). Abebe Aemro Selassie (Senior Resident Representative) assisted the mission.

- $\quad$ Mission. Discussions for the fifth review under the PSI took place in Kampala during March 25-April 7, 2009. The mission met with the Minister of Finance, Planning and Economic Development, Ms. Bbumba; Bank of Uganda Governor Tumusiime Mutebile; other senior officials; and representatives of the private sector, civil society and development partners. The staff in the resident representative office provided valuable support to the mission. 


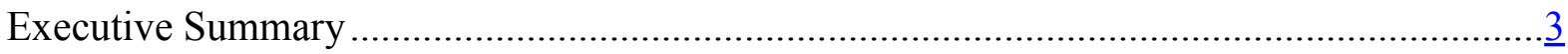

I. Recent Developments and Program Performance ..............................................................

II. The Macroeconomic Outlook and Risks .........................................................................

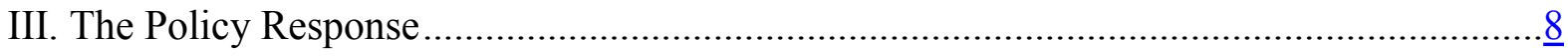

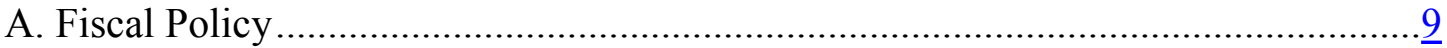

B. Monetary and Financial Policies ………………............................................... 10

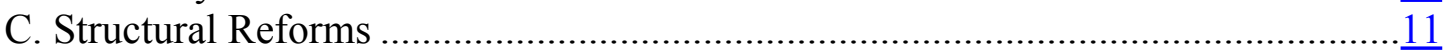

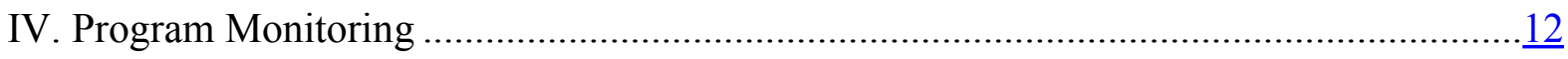

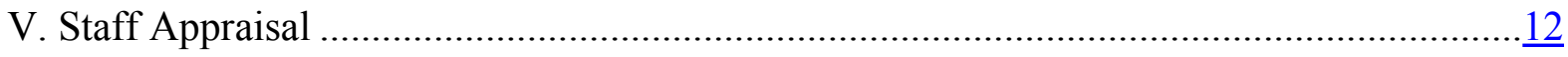

Tables

1. Selected Economic and Financial Indicators, FY2006/07-2012/13 …...............................14

2. Fiscal Operations of the Central Government, FY2006/07-2012/13 …………….............15

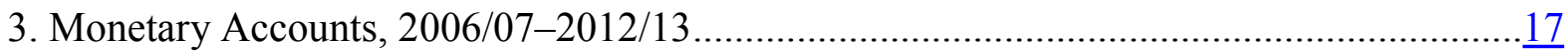

4. Balance of Payments, 2006/07-2012/13 .....................................................................

5. Quantitative Assessment Criteria and Indicative Targets for end-September 2008 and

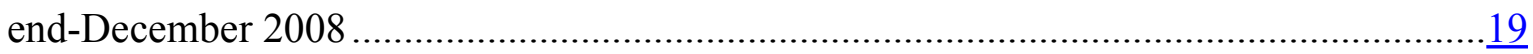

6. Structural Assessment Criterion and Benchmark .............................................................

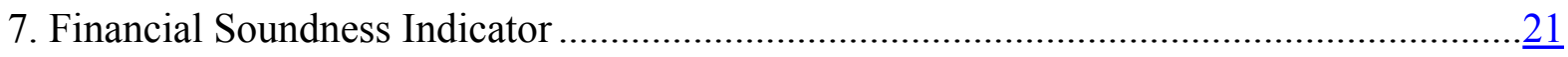

Figures

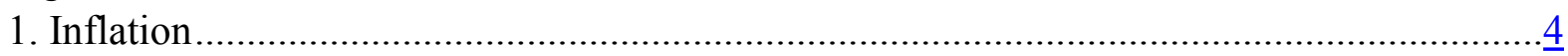

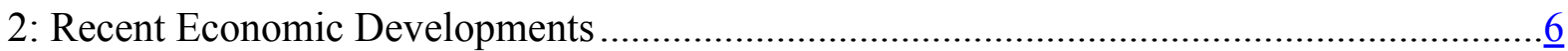

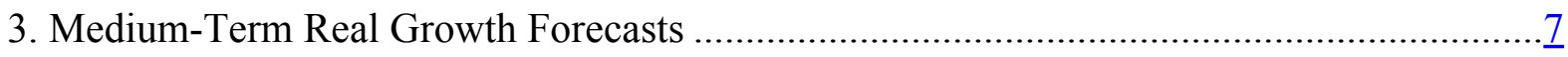

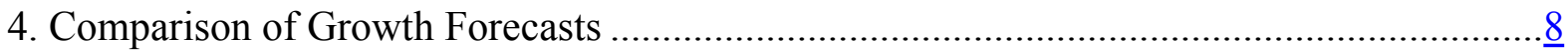

Appendix

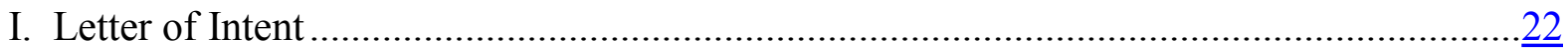

Attachment I. Memorandum of Economic and Financial Policies Update .........................24

Table 1. Quantitative Assessment Criteria and Indicative Targets for March 2009-

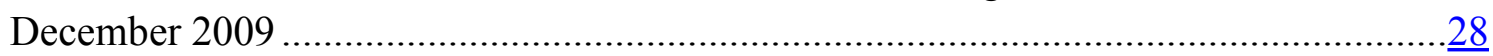

Table 2. Proposed Structural Benchmarks.........................................................................29

Attachment II. Technical Memorandum of Understanding ..............................................

Table 1. Summary of Reporting Requirements …………………………........................ 


\section{Executive Summary}

The global financial crisis is affecting Uganda but macroeconomic performance has been strong. After several years of impressive growth (an average of about $91 / 2$ percent over the past three years), the pace of activity is expected to decline to 5-6 percent in FY2008/092009/10, still high by global and regional standards. Despite the challenges, policy implementation continues to be strong; all assessment criteria for the fifth review have been met; both headline and core inflation have begun to decelerate; and foreign exchange reserves remain comfortable.

Strong fundamentals and prudent economic policies of the past give Uganda scope to implement measured counter-cyclical policies without undermining macroeconomic stability. Monetary policy has been gradually eased in the face of the dry-up in private external financing. In spite of the slowdown-induced shortfall in tax revenue, the fiscal authorities are committed to accelerate and improve execution of investment spending to provide a positive impulse to growth and remove critical bottlenecks, but they intend to compress current spending to limit the size of the fiscal deficit. Staff see scope for maintaining recurrent outlays, to facilitate an efficient public service delivery and further stimulate the economy, without an inflationary impact or undue draw down in reserves. The authorities agreed to revisit their budget proposal before sending it to Parliament for approval.

The Bank of Uganda (BOU) is developing modalities to respond more flexibly to unanticipated liquidity shocks. With technical assistance from MCM, the authorities are working on refinements to the current liquidity management framework to provide a more flexible response to sudden developments - including by assessing possible changes to the BOU's very short-term liquidity management instruments.

Uganda's financial system has been relatively insulated from the direct impact of the global financial crisis. Recent indicators suggest that vulnerabilities to credit and exchange rate risks remain limited; but the slowdown in growth, if prolonged, could pose challenges. The authorities have taken significant steps to enhance their capacity to respond to an emerging crisis. Nevertheless, staff underscored the importance of preparing explicit contingency plans for handling a systemic banking crisis.

Downside risks remain high given the uncertain external environment. A steeper, more protracted global downturn as well as delays in the resolution of the global financial crisis would adversely affect Uganda's fiscal and external accounts and could undermine confidence and raise new vulnerabilities.

The PSI supported program remains on track. All assessment criteria for the fifth review have been met and staff recommends completion of the review. 


\section{Recent Developments and Program Performance}

1. After several years of high growth and strong macroeconomic performance, the global financial crisis is now constraining economic activity in Uganda. Trade flows, remittances, official project aid, and portfolio inflows have weakened, especially during the last quarter of 2008; tax revenue collections have underperformed; and bank liquidity has tightened, pushing up domestic interest rates. Reflecting the reduced foreign exchange inflows, the shilling/dollar exchange rate has depreciated by about 30 percent since October. Nonetheless, international reserves have remained at a comfortable level (about 5 months of imports).

2. Inflation has begun to ease down in spite of continued high food prices. Last year's surge in international food and fuel prices pushed 12-month inflation to a record 15.9 percent in August 2008. Inflation has been decelerating since then, albeit slowly, reaching about 14 percent in March 2009. Food inflation has remained high throughout the period, reflecting an increase in demand from neighboring countries as well as persistent supply rigidities, while core inflation net of its food components declined to less than 9 percent.

Figure 1. Inflation (annual percentage change)
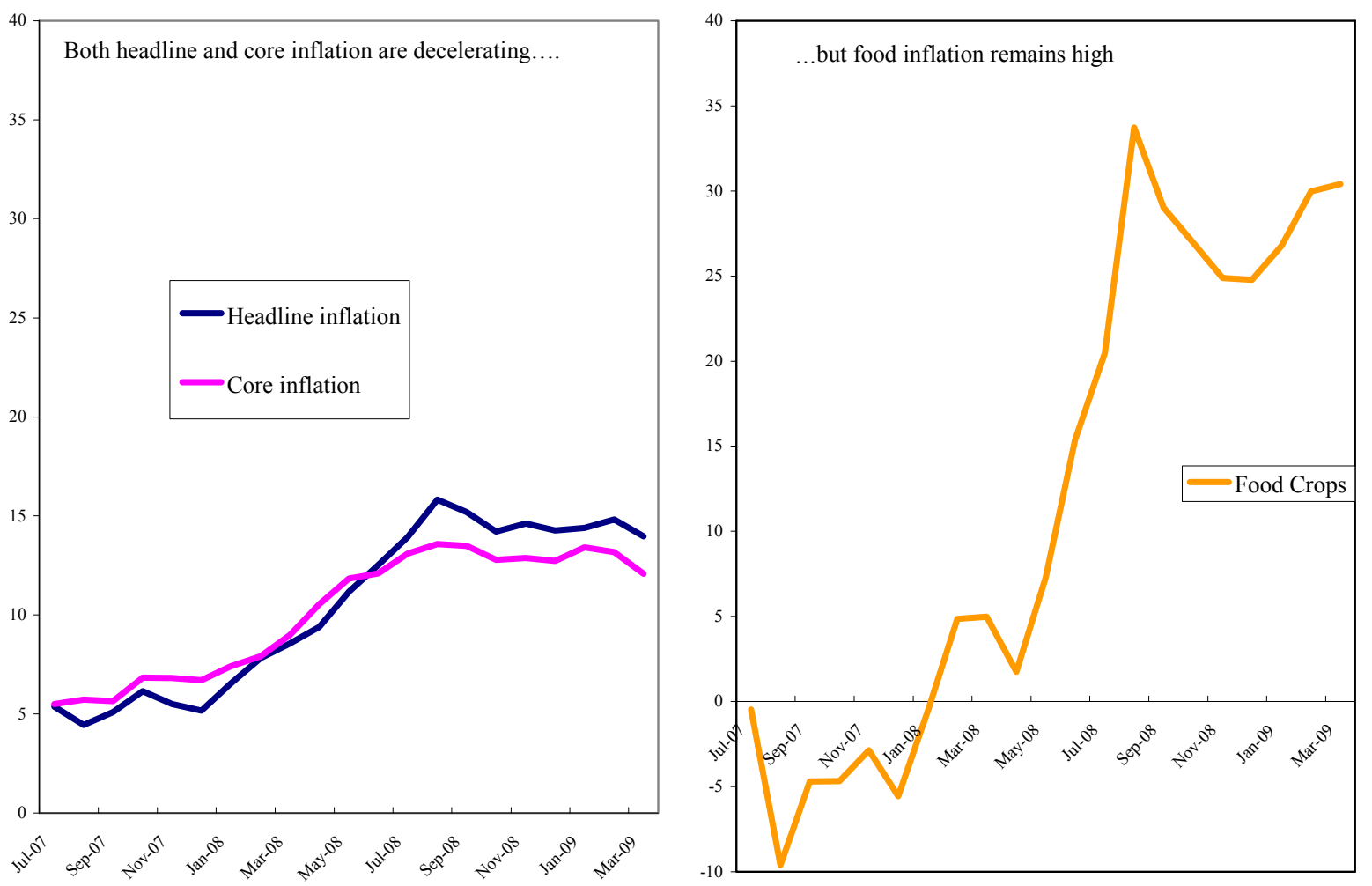

Source: Uganda Authorities 
3. Constraints to execution of the investment budget have kept the fiscal deficit in check, despite a shortfall in tax revenue. Data for the first six months of FY2008/09 point to a shortfall of more than 4 percent in domestic revenue - mainly company taxes, petroleum duties, and VAT — due to weaker-than-expected economic activity. ${ }^{1}$ At the same time, expenditures were also lower than planned as capacity constraints slowed down implementation of infrastructure projects. Accordingly, the overall fiscal deficit (excluding grants) for the first half of FY 2008/09 was 1.8 percent of GDP, 1.7 percentage point lower than targeted.

4. Monetary policy was cautiously relaxed in the face of lower external financing and resulting volatility in domestic money markets. The reversal in foreign inflows, coupled with heightened financial uncertainties, led to unexpected shifts in liquidity and money demand and a spike in interest rates. In response, the monetary authorities stepped up their provision of short-term liquidity to banks and subsequently reduced issuance of government securities, facilitating the return of interest rates to their previous levels.

5. The banking system remains sound and well capitalized. Bank solvency indicators and stress tests' results suggest that vulnerabilities to credit and exchange rate risks remain limited. Reflecting the softening of private sector demand and more cautious lending practices, the growth rate of credit to the private sector (month on month) slowed down to under 1 percent in the first two months of 2009 compared to an average of about 4 percent in 2008 .

6. All assessment criteria (AC) for end-December 2008 have been met. The ceilings on net domestic assets of the Bank of Uganda (BOU) and on net credit to government were observed by a wide margin and the floor on the net accumulation of international reserves was met despite the strong reversal in portfolio inflows. The assessment criteria on the stock of external repayment arrears, new nonconcessional borrowing and new short-term external debt were also observed. The indicative target on base money was exceeded by a small margin, reflecting the central bank's response to unexpected increases in the demand for liquidity at the end of the year. With respect to structural measures, the submission to Parliament of a draft regulatory framework for pension funds - a structural benchmark for end-December - was not met due to implementation of a broad-based consultation process with the private sector and other important stakeholders. Submission to Parliament is now expected by the summer.

\footnotetext{
${ }^{1}$ The fiscal year starts on July 1.
} 
Figure 2: Recent Economic Developments

Both exports and imports have weakened since September 2008

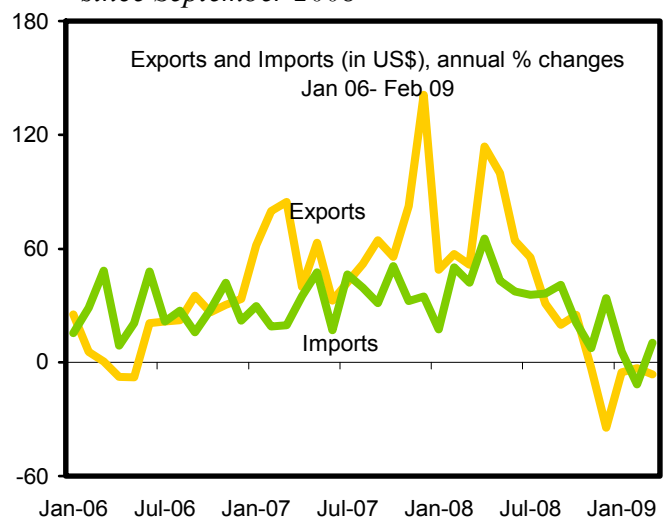

The exchange rate has depreciated

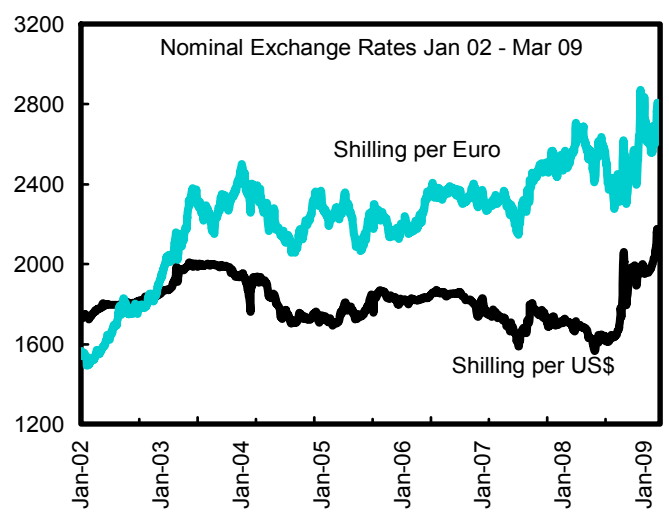

Tax revenues have also underperformed

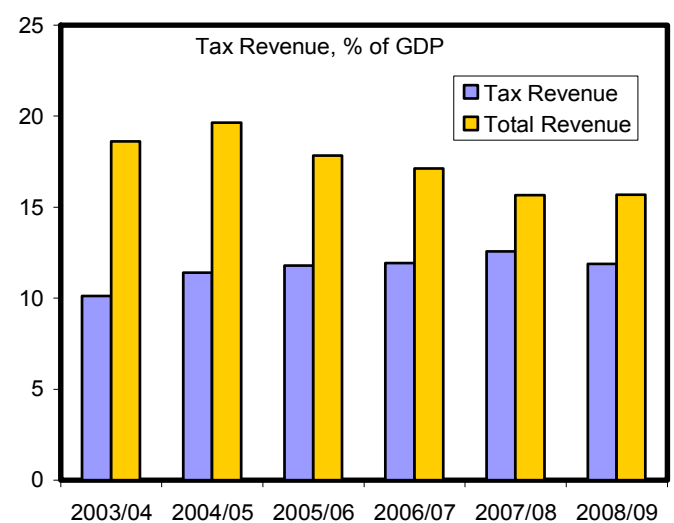

Interest rates increased due to tight liquidity conditions

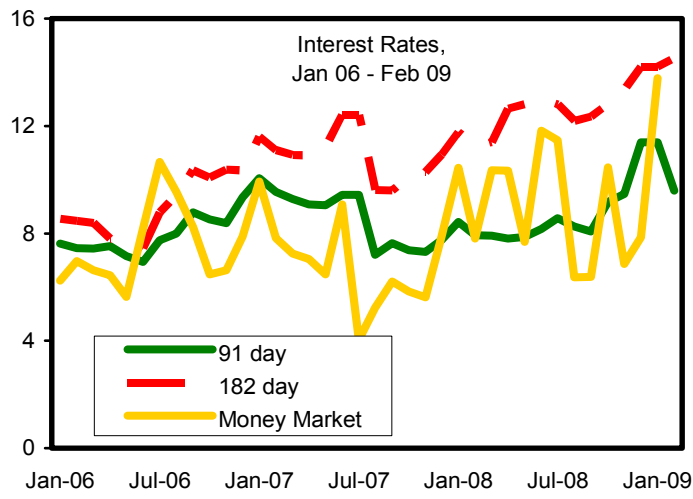

In response to tight liquidity conditions, monetary policy was eased including by reducing issuance of government securities.

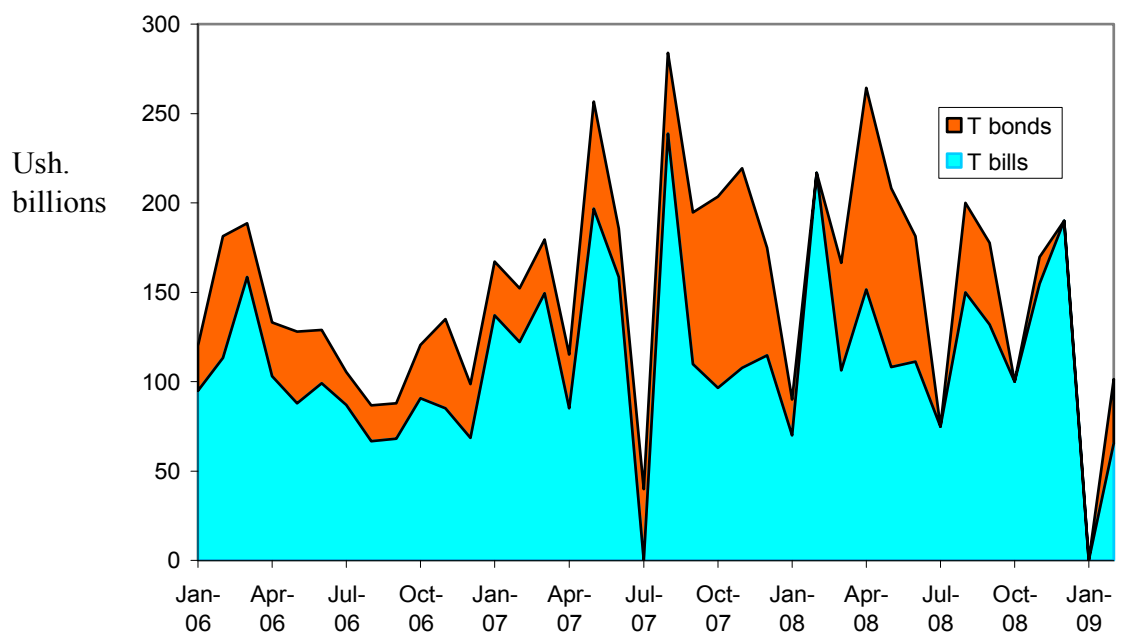

Source: Ugandan authorities and Fund staff estimates 


\section{The Macroeconomic OUTLOOK AND RISKS}

7. Real GDP growth is expected to fall to 5-6 percent (from $9 \frac{1}{2}$ percent over the past 3 years) as global developments continue to shape the path of the Ugandan economy. Lower global demand will reduce the volume and price of Ugandan exports and constrain remittances and foreign investment, two important supports of private demand in the recent period. There are indications that activity in Uganda began to soften in the second half of 2008, following world output with a lag. Staff expect these transmission mechanisms to intensify in the near term, with growth decelerating further and remaining below potential through early 2011. Output would rebound gradually in the outer years, in line with the path of world growth. ${ }^{2}$
Figure 3. Uganda: Medium-Term Real Growth Forecasts (annual percentage change)

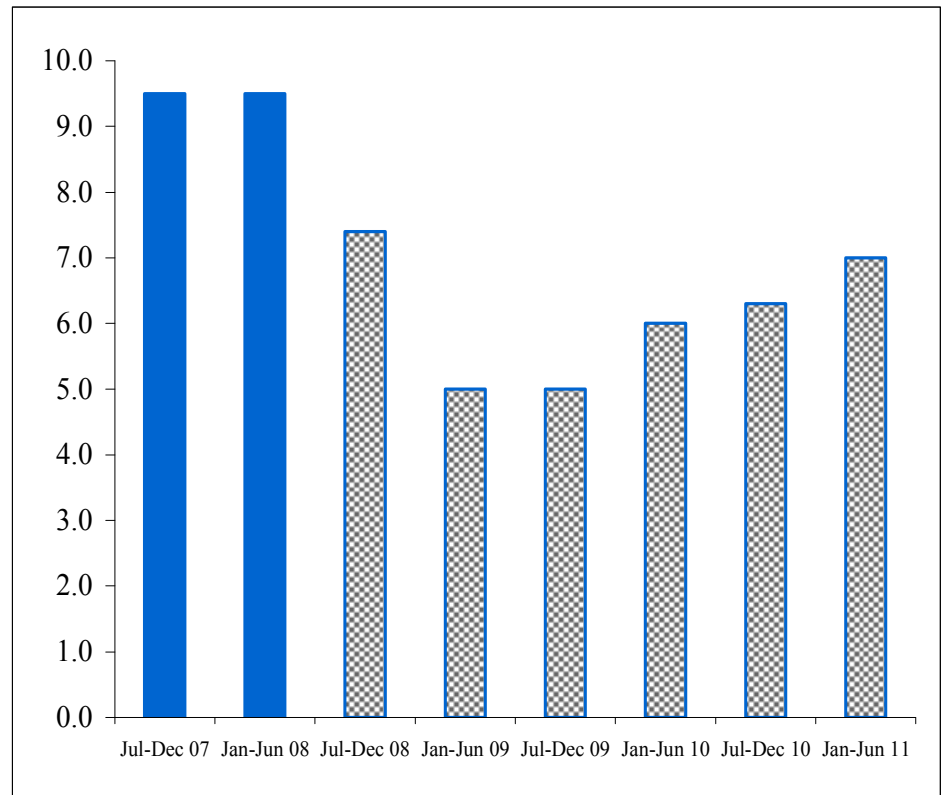

\section{Strong fundamentals and continued prudent macroeconomic policies should} enable the Ugandan economy to absorb the slowdown in growth without major macroeconomic stress. Core inflation is projected to decline to about 10 percent by end FY2008/09 (year on year), supported by global disinflation and a gradual normalization in the regional demand and supply of food. With prudent monetary management, inflation should converge to its medium-term objective of 5 percent by 2010. The FY 2009/10 external current account deficit, excluding grants, is expected to widen to more than 10 percent of GDP as higher donor-financed capital expenditure, lower merchandise exports, and declining private transfers outweigh the positive impact of lower oil prices on the trade balance. International reserves are projected to decline but remain comfortably above 4 months of import, thanks in part to continued aid inflows. External balances are projected to revert to a sustainable position in the medium term as the world economy recovers.

\section{These projections are subject to significant uncertainties, most of them on the} downside. A steeper, more protracted global downturn as well as delays in the resolution of

\footnotetext{
${ }^{2}$ The medium-term growth path does not incorporate possible future oil output as exploration activity has not yet determined the size and economic value of oil reserves. Preliminary indications are that oil production would not start before 2011 at the earliest.
} 
the global financial crisis could prolong the slowdown, worsen the fiscal and external accounts and begin to imperil bank soundness. Were international trade and financial flows to remain sluggish, the recovery in advanced economies could also come to Uganda with a longer lag than currently projected. This would depress tax revenue further and limit the scope for budget spending. Given its still relatively shallow domestic financial markets, Uganda remains vulnerable to unexpected confidence shifts. More importantly, lingering budget constraints in advanced economies could adversely affect aid flows. On the other hand, the authorities believe that their ongoing investment plans, together with the country's large agricultural potential, could provide a buffer against the external shock. In all, growth in Uganda, even if halved under current forecasts, would still remain among the highest in sub-Saharan Africa and the world, reflecting a low dependence on commodity exports, extensive structural reforms, and a sound financial system.

Figure 4: Comparison of Growth Forecasts

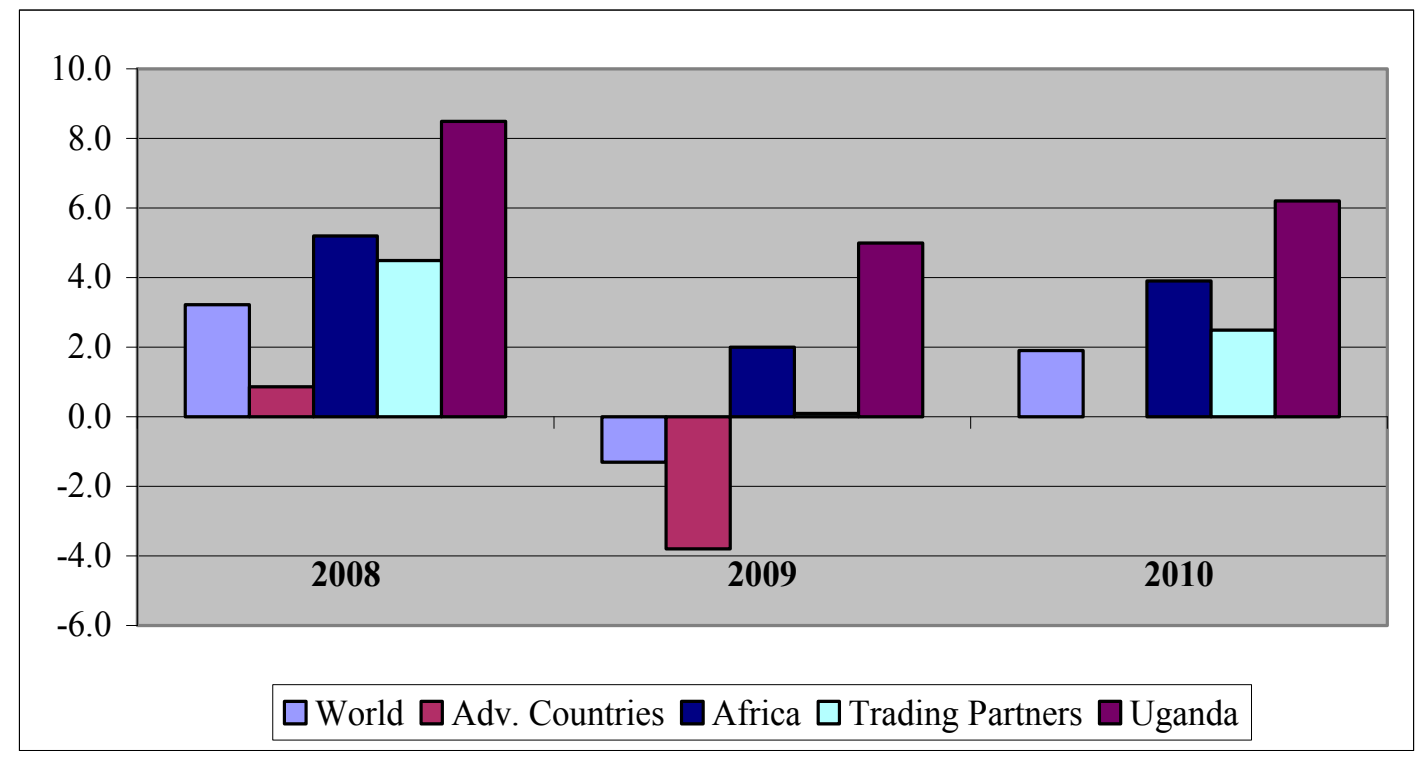

III. The Policy Response

10. Discussions focused on policies to mitigate the impact of the global crisis without undermining market confidence or endangering Uganda's medium-term sustainability and growth prospects. Prudent economic management of recent years has given Uganda scope to protect itself to some extent against the effects of this external shock. The public debt-to-GDP ratio is low, domestic financial markets are relatively stable, and international reserves above standard safety levels. The policy dialogue centered on the possible extent, composition and modalities of a counter-cyclical policy mix. 


\section{A. Fiscal Policy}

\section{Full execution of the current budget would provide a strong and welcome} positive impulse to short-term growth. The FY 2008/09 budget initiated an ambitious three-year infrastructure development program - partly financed by external borrowingwith large electricity generation and transportation projects aimed at removing bottlenecks deemed critical for Uganda's productive and export capacity. As revenues are now expected to underperform by about 0.5 percent of GDP, the overall deficit (excluding grants) in the revised budget is projected to increase to 7 percent of GDP, from 4.8 percent of GDP in FY2007/08. It would still fall short of the programmed level of 7.7 percent of GDP because of delays in capital spending in the first half of the fiscal year.

\section{Raising budget implementation for the remainder of FY 2008/09 will be} challenging. The authorities are committed to accelerate the execution of investment projects and have taken important steps to that end, including a reform of procurement laws, streamlining of administrative processes, and closer monitoring. However, capacity constraints may well continue to hinder project implementation in the near term. Against that background, staff cautioned the authorities to exercise care in balancing speed against efficiency so as to guard against a wasteful, disorderly use of public resources.

\section{The fiscal policy stance for FY 2009/10 outlined in the National Budget}

Framework Paper risks imparting a contractionary impact on economic activity. Plans are to sustain a high level of development spending but compress current spending, so that total public outlays would decline by about one percentage point of GDP at a time when economic activity remains below potential. The contractionary effect would be even more pronounced if the execution of capital expenditures were lower than targeted, as has been the norm in recent years. ${ }^{3}$

\section{There are risks that large, lasting cuts in current spending propagate} inefficiency and undermine sound budget management. Over recent years, the government's wage bill has declined continuously as a share of GDP. Low wage growth can adversely impact service delivery as well as constrain implementation capacity in government agencies. ${ }^{4}$ Relatedly, under budgeting of operational and maintenance outlays can lower investment returns and undermine sound budget execution, particularly if public financial management (PFM) is weak. Evidence that the compression of recurrent spending has become close to impossible to sustain includes the build-up in new government domestic payment arrears (from 0.1 percent of GDP in FY2005/06 to 0.2 percent of GDP in FY2006/07 and 0.3 percent of GDP in FY2007/08) in spite of efforts to reduce the stock of existing arrears (an indicative target under the program).

\footnotetext{
${ }^{3}$ The latest PEFA report on public financial management confirms that under spending remains widespread across ministries in Uganda.

${ }^{4}$ The low wage bill may not fully capture all elements of staff compensation because of classification problems.
} 
15. Staff see scope for a cautious fiscal easing that would maintain both current and capital outlays broadly stable as a share of GDP in spite of the projected decline in revenue, delivering a more balanced composition of spending while providing some fiscal stimulus to the economy. The fiscal deficit, rather than declining, would remain at about 7 percent of GDP (excluding grants), although a projected decline in budget support would raise domestic financing needs compared to the previous year. The expected slowdown in private demand for credit would leave scope for accommodating part of the resulting draw down in government bank deposits (of about 1 percent of GDP) without much crowding out or inflationary impact. Excess liquidity would be mopped up through foreign exchange sales and a reduction in the stock of international reserves. The fiscal authorities should stand ready to revisit their spending plans should tax collections fall markedly short of projections. They could delay the implementation of part of their investment projects while safeguarding the planned allocation to the Poverty Action Fund (an indicative target under the program).

\section{The authorities intend to revisit and flesh out their budget proposal before} submitting it for Parliamentary approval. They are committed to limit fiscal spending to a level that can be credibly financed and sustainable over the medium term. They pointed out that successive years of cautious fiscal management has supported strong growth without unduly constraining monetary policy or exerting pressure on international reserves. They also noted that blanket increases in current spending would not guarantee higher public sector efficiency, but agreed to look more closely for possible under budgeting areas.

\section{In staff's views, a short-term expansionary fiscal stance is unlikely to} jeopardize Uganda's hard-won gains in macroeconomic stability. Revenues are expected to rebound over the medium term as economic growth recovers and tax administration reforms yield additional revenue. At the same time, budget spending levels are expected to decline as the large infrastructure projects near completion. Domestic financing would gradually decline from a peak of 1 1/2 percent of GDP in FY2009/10 to 0.3 percent in 2012 and beyond, leaving adequate room for private credit growth. In light of the expected phasing out of the large projects, as well as the low level and highly concessional terms of Uganda's public debt, the increase in the fiscal deficit can be limited in time and not endanger medium-term sustainability.

\section{B. Monetary and Financial Policies}

18. Monetary policy will continue to focus on disinflation while providing adequate liquidity to support a healthy level of economic activity. There was broad agreement that the recent, cautious monetary easing was justified by the drying up of private external financing and downturn in demand. Inflation, while still higher than envisaged, is largely the product of exogenous factors - mostly, strong regional demand for food, high transportation costs and supply rigidities - and it is expected to abate as these factors unwind. Against that background, the money growth target will be increased slightly, to 
about 20 percent in FY 2008/09. Similar prudent easing of monetary policy will continue in FY 2009/10. The authorities expressed their readiness to adjust their policies should inflationary pressures spread further.

\section{Non-inflationary accommodation of the fiscal stimulus in FY 2009/10 would} likely entail a modest drawdown in the BOU's international reserves. However, at more than $4 \frac{1}{2}$ months of imports, they would remain above existing minimum comfort levels. There was agreement that the recent depreciation of the shilling largely reflected the market response to the reduction in external inflows. The BOU reiterated its longstanding policy of letting market forces determine the exchange rate, intervening in foreign exchange markets only to smooth out excessive volatility.

\section{The BOU is developing modalities to respond more flexibly to unanticipated} liquidity shocks. Recent developments in financial markets exposed shortfalls in BOU's capacity to address short-term liquidity pressures. With technical assistance from MCM, the authorities are working to enhance the flexibility of the current liquidity management framework in response to unanticipated shocks - including by assessing possible changes to the BOU's very short-term liquidity management instruments. Staff will continue to collaborate with the BOU in this effort.

\section{The BOU has taken important steps to intensify oversight of domestic banks'} exposures and enhance its crisis response capacity. Uganda's financial system has so far been insulated from the direct impact of the global financial crisis and vulnerabilities to interest and exchange rate risk are low. Nevertheless, the supervisory authorities have taken significant steps to enhance their capacity to respond to a crisis should it emerge-if, for example, a more pronounced slowdown led to a deterioration in the quality of the banks' assets. In particular, they have begun to collect more frequent and higher-quality data on banks' balance sheets and are strengthening cross-border supervisory arrangements. Staff encouraged the authorities to prepare explicit contingency plans for handling a systemic banking crisis.

\section{Structural Reforms}

22. Looming resource constraints provide a stage to renew momentum with public financial management reforms. The authorities reiterated their commitment to measures to improve tax administration, in particular by enhancing the efficiency of tax collection agencies. Staff encouraged the authorities to speed up reforms to increase absorption capacity in the key spending agencies. This will facilitate a more effective implementation of planned growth-enhancing public investments and ensure better value for money in public spending. There has been some progress towards implementation of an integrated personnel and payment system in selected ministries (currently a structural assessment criterion under the PSI but proposed to be converted to a structural benchmark), although with some delays, largely reflecting supply and capacity constraints. 


\section{Program Monitoring}

23. The quantitative assessment criteria for end-June 2009 and the sixth review of the PSI are presented in the authorities' Memorandum of Economic and Financial Policies (MEFP) (Attachment I to the Letter of Intent). It is proposed that some of these assessment criteria be revised from those established at the time of the fourth review, in line with the new economic circumstances. Specifically, the ceiling on the increase in net domestic assets of the Bank of Uganda should be raised to reflect the modest easing of the monetary stance. The assessment criteria on net bank claims to the central government and on net international reserves should be marginally modified to reflect outcomes in the first part of the fiscal year. Table 2 of the MEFP presents the structural measures that are being proposed to be monitored under the PSI.

\section{Staff Appraisal}

24. The global economic downturn is beginning to have an impact on Uganda. With lower exports and financing inflows, growth is expected to slow to 5-6 percent in the coming years and recover only gradually, in line with world output. This would still compare favorably with outcomes in other parts of Africa and the world, thanks in good part to successive years of sound reforms and cautious macroeconomic management.

25. Staff see scope for an easing of the near-term fiscal stance. The authorities are cautiously adjusting their fiscal policy in light of the changed economic circumstances. Low public debt and comfortable levels of international reserves give them scope for maintaining public investment plans as well as current spending without undermining hard-won sustainability, in spite of the expected slowdown-induced shortfall in tax revenue. This would provide timely support to near-term activity while addressing critical bottlenecks to Uganda's productive and export capacity.

26. Enhanced budget execution and a balanced distribution of spending are critical to the success of the fiscal plans. The implementation of investment projects is lagging, largely because of pervasive capacity constraints. Stepped-up implementation of management reforms would facilitate a more efficient and orderly execution of public programs. Similarly, a more careful balancing of current and capital spending could help mitigate capacity constraints and stem the increasing trend in expenditure arrears.

\section{Monetary management has shown an appropriate combination of flexibility} and caution. The gradual relaxing of monetary targets was a prudent response to the drying up in external private finance in a context of high uncertainties and persistent food-based inflation. Looking forward, the monetary stance could continue to ease if inflation remains on a downward path and private demand softens, although the authorities should remain watchful of a possible re-emergence of price pressures. In addition, the authorities may wish to explore options to fine-tune their short-term monetary instruments to increase their flexibility in the face of unanticipated shocks. 
28. The PSI-supported program is on track. All assessment criteria for the fifth review have been met, and staff recommends completion of the review. Based on the strength of the authorities' policies, staff support the modifications to the program's endJune 2009 assessment criteria and the conversion of the structural assessment criterion on implementation of an integrated personnel and payment system into a structural benchmark, in line with Board guidance on structural conditionality. 
Table 1. Uganda: Selected Economic and Financial Indicators, FY2006/07-2012/13 ${ }^{1}$

\begin{tabular}{|c|c|c|c|c|c|c|c|c|}
\hline \multirow{3}{*}{ GDP and prices (percent change) } & \multirow{2}{*}{$\begin{array}{r}2006 / 07 \\
\text { Act. }\end{array}$} & \multirow{2}{*}{$\begin{array}{r}2007 / 08 \\
\text { Est. }\end{array}$} & \multicolumn{2}{|c|}{$2008 / 09$} & \multirow{2}{*}{$\begin{array}{r}2009 / 10 \\
\text { Proj. }\end{array}$} & \multirow{2}{*}{$\begin{array}{r}2010 / 11 \\
\text { Proj. }\end{array}$} & \multirow{2}{*}{$\begin{array}{r}2011 / 12 \\
\text { Proj. }\end{array}$} & \multirow{2}{*}{$\begin{array}{r}2012 / 13 \\
\text { Proj. }\end{array}$} \\
\hline & & & Prog. & Rev. Prog & & & & \\
\hline & \\
\hline Real GDP & 8.6 & 9.5 & 7.4 & 6.2 & 5.5 & 6.7 & 7.0 & 7.0 \\
\hline Headline inflation (end of period) & 4.4 & 12.5 & 7.7 & 10.3 & 6.2 & 5.4 & 5.6 & 5.9 \\
\hline Core inflation (end of period) & 7.3 & 12.1 & 7.0 & 10.3 & 6.0 & 5.0 & 5.0 & 5.0 \\
\hline External sector (percent change) & & & -- & & & & & \\
\hline Terms of trade (deterioration -) & 5.5 & -2.5 & -- & -- & -2.5 & -1.1 & $\ldots$ & $\ldots$ \\
\hline Real effective exchange rate (depreciation -) & 2.7 & -1.3 & $\ldots$ & $\ldots$ & $\ldots$ & $\ldots$ & $\ldots$ & $\ldots$ \\
\hline \multicolumn{9}{|l|}{ Money and credit (percent change) } \\
\hline Broad money (M2) & 16.7 & 30.3 & 18.0 & 20.9 & 16.6 & 17.9 & 17.9 & 17.9 \\
\hline Domestic credit & -6.4 & 22.0 & 16.2 & 17.8 & 21.8 & 16.4 & 15.4 & 13.1 \\
\hline Credit to the central government ${ }^{2}$ & -17.2 & -4.3 & 1.4 & 1.3 & 6.0 & 3.5 & 2.2 & -0.3 \\
\hline Private sector credit & 22.9 & 56.1 & 26.4 & 29.6 & 26.3 & 19.9 & 19.9 & 19.9 \\
\hline \multicolumn{9}{|l|}{ Savings and investment (percent of GDP) } \\
\hline Domestic investment & 22.1 & 23.6 & 27.3 & 25.3 & 26.3 & 26.2 & 25.6 & 25.7 \\
\hline Public & 4.9 & 5.5 & 9.2 & 7.7 & 8.7 & 8.3 & 7.2 & 6.8 \\
\hline Private & 17.2 & 18.1 & 18.1 & 17.6 & 17.6 & 17.9 & 18.4 & 18.9 \\
\hline National savings (excluding grants) & 14.5 & 17.4 & 17.7 & 14.6 & 15.5 & 18.3 & 19.6 & 20.3 \\
\hline Public & -0.7 & 0.7 & 2.3 & 0.7 & 1.8 & 2.4 & 2.2 & 2.9 \\
\hline Private & 15.2 & 16.7 & 15.4 & 13.9 & 13.7 & 15.9 & 17.4 & 17.4 \\
\hline \multicolumn{9}{|l|}{ External sector (percent of GDP) } \\
\hline Current account balance (including grants) & -3.1 & -3.2 & -5.3 & -6.2 & -6.5 & -4.6 & -2.9 & -2.6 \\
\hline Current account balance (excluding grants) & -7.6 & -6.2 & -9.6 & -10.7 & -10.8 & -7.9 & -6.0 & -5.4 \\
\hline Net donor inflows & 6.5 & 4.9 & 7.0 & 7.3 & 7.1 & 5.2 & 4.1 & 3.5 \\
\hline External debt (including Fund) & 11.0 & 12.3 & 13.9 & 17.3 & 20.5 & 22.4 & 24.1 & 25.2 \\
\hline External debt-service ratio ${ }^{3,4}$ & 1.2 & 1.4 & 1.8 & 1.8 & 1.6 & 1.1 & 1.1 & 0.9 \\
\hline \multicolumn{9}{|l|}{ Government budget and debt (percent of GDP) } \\
\hline Revenue & 12.6 & 13.0 & 12.9 & 12.4 & 12.3 & 12.6 & 12.8 & 13.6 \\
\hline Grants & 4.5 & 2.7 & 4.1 & 3.2 & 3.0 & 2.9 & 3.0 & 2.7 \\
\hline Total expenditure and net lending & -18.2 & -17.8 & -20.6 & -19.4 & -19.1 & -18.6 & -17.8 & -17.5 \\
\hline Overall balance (including grants) & -1.1 & -2.1 & -3.5 & -3.7 & -3.9 & -3.1 & -2.0 & -1.2 \\
\hline Overall balance (excluding grants) & -5.6 & -4.8 & -7.7 & -7.0 & -6.9 & -5.9 & -5.0 & -3.9 \\
\hline Stock of domestic debt & 9.3 & 10.7 & 7.7 & 8.6 & 7.2 & 5.8 & 5.0 & 4.1 \\
\hline \multicolumn{9}{|l|}{ Memorandum items: } \\
\hline Nominal GDP (U Sh billions) & 21,168 & 24,648 & 30,782 & 30,496 & 34,489 & 39,240 & 44,284 & 50,597 \\
\hline Average exchange rate (U Sh per US\$) & 1,778 & 1,696 & $\ldots$ & $\ldots$ & $\ldots$ & $\ldots$ & $\ldots$ & $\ldots$ \\
\hline Treasury bill yield (percent) & 9.4 & 8.3 & $\ldots$ & $\ldots$ & $\ldots$ & $\ldots$ & $\ldots$ & $\ldots$ \\
\hline Overall balance of payments (US\$ millions) & 704 & 563 & -92 & -100 & -144 & -81 & 37 & 124 \\
\hline \multicolumn{9}{|l|}{ Gross foreign exchange reserves } \\
\hline (months of next year's imports of goods and services) & 5.4 & 6.2 & 5.7 & 5.2 & 4.9 & 4.6 & 4.4 & 4.2 \\
\hline
\end{tabular}

Sources: Ugandan authorities; and IMF staff estimates and projections.

${ }^{1}$ Fiscal year begins in July.

2 Percent of M3 at start of the period.

${ }^{3}$ Percent of exports of goods and nonfactor services.

${ }^{4}$ Including Fund obligations; reflects actual debt service paid, including debt relief. 
Table 2. Uganda: Fiscal Operations of the Central Government, FY2006/07-2012/13

\begin{tabular}{|c|c|c|c|c|c|c|c|c|c|}
\hline & \multirow{2}{*}{$\begin{array}{r}\text { 2006/07 } \\
\text { Actual }\end{array}$} & \multirow{2}{*}{$\begin{array}{r}2007 / 08 \\
\text { Actual } \\
\end{array}$} & \multicolumn{2}{|c|}{$2008 / 09$} & \multicolumn{2}{|c|}{$2009 / 10$} & \multirow{2}{*}{$\begin{array}{r}\text { 2010/11 } \\
\text { Proj. }\end{array}$} & \multirow{2}{*}{$\begin{array}{r}\text { 2011/12 } \\
\text { Proj. }\end{array}$} & \multirow{2}{*}{$\begin{array}{r}2012 / 13 \\
\text { Proj. } \\
\end{array}$} \\
\hline & & & Prog. & Rev. Prog & $\begin{array}{l}\text { Budget } \\
\text { (NBFP) }\end{array}$ & Staff Proj. & & & \\
\hline & \multicolumn{2}{|c|}{ (U Sh Billions) } & & & & & & & \\
\hline Total revenue and grants & 3,624 & 3,860 & 5,167 & 4,779 & 5,385 & 5,260 & 6,075 & 7,022 & 8,265 \\
\hline Revenue & 2,667 & 3,200 & 3,892 & 3,791 & 4,397 & 4,231 & 4,956 & 5,688 & 6,885 \\
\hline Tax & 2,524 & 3,098 & 3,788 & 3,625 & 4,282 & 4,115 & 4,856 & 5,607 & 6,794 \\
\hline International trade taxes & 261 & 382 & 460 & 502 & n.a. & 589 & 708 & 818 & 991 \\
\hline Income taxes & 782 & 862 & 1,161 & 1,043 & n.a. & 1,172 & 1,369 & 1,622 & 1,968 \\
\hline Excises & 653 & 815 & 905 & 898 & n.a. & 998 & 1,145 & 1,348 & 1,622 \\
\hline Value-added tax & 829 & 1,039 & 1,169 & 1,091 & n.a. & 1,253 & 1,439 & 1,597 & 1,945 \\
\hline Additional revenue effort & 0 & 0 & 92 & 91 & 103 & 103 & 196 & 221 & 268 \\
\hline Nontax & 144 & 102 & 104 & 166 & 115 & 115 & 100 & 81 & 91 \\
\hline Grants & 957 & 660 & 1,275 & 988 & 987 & 1,030 & 1,119 & 1,334 & 1,380 \\
\hline Budget support & 776 & 475 & 521 & 528 & 441 & 483 & 556 & 930 & 1,063 \\
\hline Project grants & 181 & 185 & 754 & 459 & 546 & 546 & 563 & 404 & 317 \\
\hline Expenditures and net lending & 3,856 & 4,384 & 6,343 & 5,913 & 6,381 & 6,600 & 7,289 & 7,888 & 8,849 \\
\hline Current expenditures & 2,442 & 2,881 & 3,102 & 3,249 & 3,302 & 3,522 & 3,981 & 4,661 & 5,366 \\
\hline Wages and salaries & 987 & 1,106 & 1,192 & 1,198 & 1,231 & 1,331 & 1,530 & 1,816 & 2,125 \\
\hline Interest payments & 236 & 309 & 358 & 365 & 379 & 379 & 384 & 364 & 353 \\
\hline Other current & 1,220 & 1,466 & 1,551 & 1,686 & 1,692 & 1,812 & 2,067 & 2,481 & 2,989 \\
\hline Development expenditures & 1,217 & 1,362 & 2,895 & 2,335 & 2,968 & 2,968 & 3,245 & 3,163 & 3,414 \\
\hline Donor-supported projects & 503 & 644 & 1,397 & 1,177 & 1,295 & 1,295 & 1,306 & 834 & 660 \\
\hline Domestic-financed & 714 & 718 & 1,445 & 1,158 & 1,674 & 1,674 & 1,939 & 2,328 & 2,754 \\
\hline Of which: add'l energy spending & 207 & 119 & 228 & 0 & 0 & 0 & 0 & 0 & 0 \\
\hline Of which: Karuma spending & 0 & 0 & 0 & 0 & 194 & 0 & 341 & 345 & 350 \\
\hline Of which: Roads (incl. transport corridor) & 0 & 0 & 538 & 533 & 583 & 583 & 667 & 0 & 0 \\
\hline Net lending and investment & 46 & -163 & -61 & -27 & -40 & -40 & -37 & -36 & -31 \\
\hline Other spending ${ }^{2}$ & 151 & 304 & 408 & 355 & 150 & 150 & 100 & 100 & 100 \\
\hline \multicolumn{10}{|l|}{ Overall balance } \\
\hline Including grants & -231 & -524 & $-1,176$ & $-1,134$ & -995 & $-1,340$ & $-1,215$ & -865 & -584 \\
\hline Excluding grants & $-1,188$ & $-1,184$ & $-2,451$ & $-2,122$ & $-1,983$ & $-2,369$ & $-2,333$ & $-2,200$ & $-1,964$ \\
\hline Excl. grants and add'I energy spending & -981 & $-1,065$ & $-2,679$ & $-2,122$ & $-1,983$ & $-2,369$ & $-2,333$ & $-2,200$ & $-1,964$ \\
\hline Financing & 174 & 553 & 1,176 & 1,134 & 995 & 1,340 & 1,214 & 865 & 584 \\
\hline External financing (net) & 379 & 619 & 843 & 899 & 825 & 825 & 797 & 509 & 447 \\
\hline Disbursement & 520 & 706 & 981 & 1,058 & 910 & 910 & 939 & 651 & 596 \\
\hline Budget support & 249 & 211 & 338 & 340 & 162 & 162 & 196 & 221 & 253 \\
\hline Project loans & 271 & 495 & 643 & 718 & 748 & 748 & 743 & 430 & 343 \\
\hline Amortization (-) & -104 & -87 & -94 & -108 & -48 & -48 & -138 & -141 & -152 \\
\hline Exceptional financing 2 & -38 & -13 & -44 & -50 & -27 & -27 & -7 & -5 & 0 \\
\hline Domestic financing (net) & -205 & -65 & 333 & 235 & 170 & 514 & 417 & 356 & 137 \\
\hline Bank financing & -562 & -164 & 71 & 65 & 20 & 364 & 247 & 186 & -33 \\
\hline Of which: MDRI-related government deposits & 56 & 46 & 35 & 39 & 35 & 35 & 33 & 9 & 1 \\
\hline Nonbank financing & 357 & 99 & 170 & 170 & 150 & 150 & 170 & 170 & 170 \\
\hline Errors and omissions/financing gap & 57 & -29 & 0 & 0 & 0 & 0 & 0 & 0 & 0 \\
\hline \multicolumn{10}{|l|}{ Memorandum items: } \\
\hline MDRI spending & 56 & 46 & 35 & 39 & 35 & 35 & 33 & 9 & 1 \\
\hline
\end{tabular}


Table 2. Uganda: Fiscal Operations of the Central Government, FY2006/07-2012/13 ${ }^{1}$ (concluded)

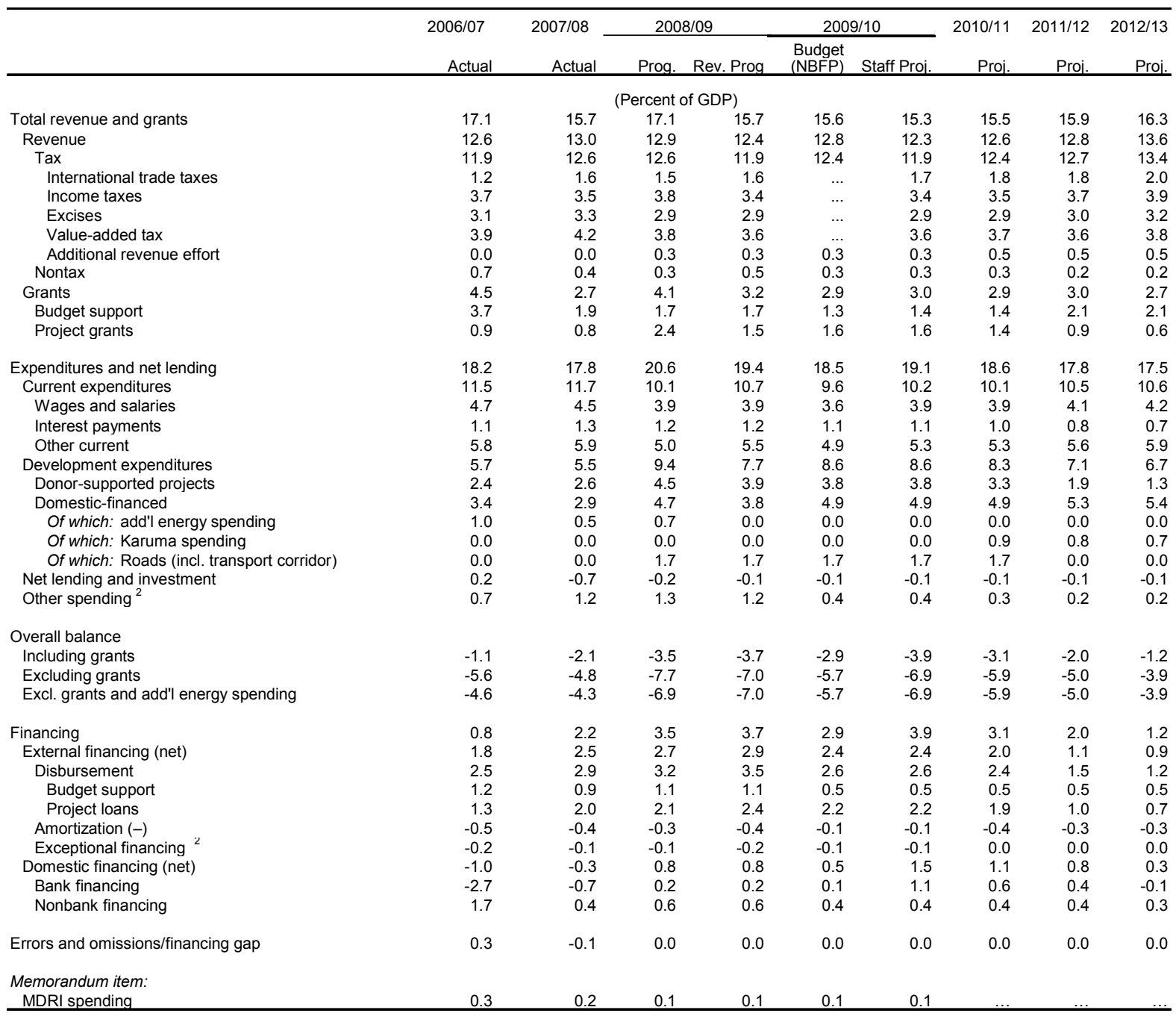

Sources: Ugandan authorities; and IMF staff estimates and projections.

${ }^{1}$ Fiscal year begins in July

${ }^{2}$ Includes arrears. 
Table 3. Uganda: Monetary Accounts, FY2006/07-2012/13 ${ }^{1}$

( $U$ Sh billions; end of period, unless otherwise indicated)

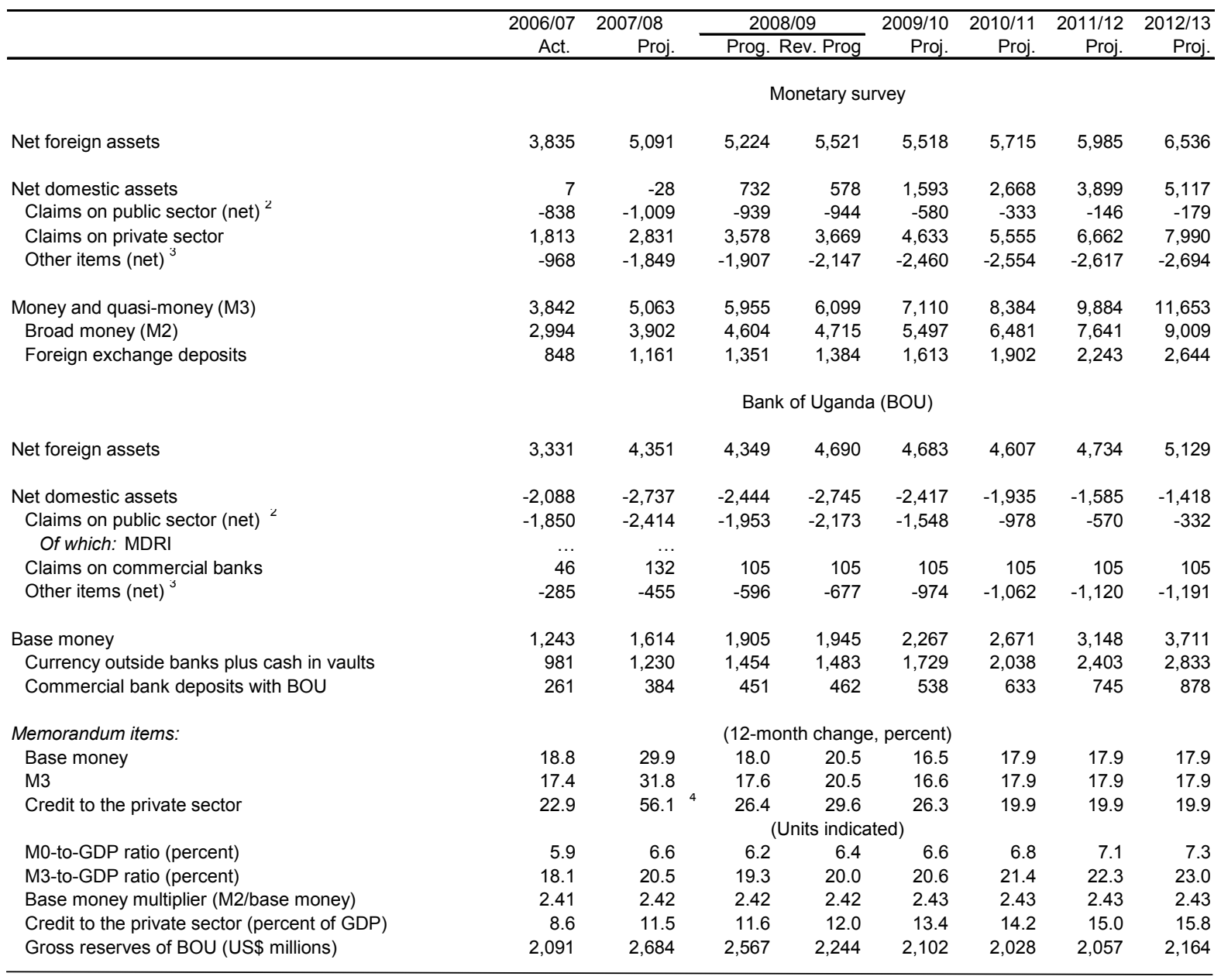

Sources: Ugandan authorities; and IMF staff estimates and projections.

${ }^{1}$ Fiscal year begins in July.

${ }^{2}$ The public sector includes the central government, the public enterprises, and the local government.

${ }^{3}$ Including valuation effects and the BOU's claims on the private sector.

${ }^{4}$ Reclassification of non-bank institutions added approximately Ush 250 bn to the stock of private sector credit. Excluding this amount, credit to the private sector grew by 40 percent. 
Table 4. Uganda: Balance of Payments, FY2006/07-2012/13 ${ }^{1}$ (US\$ millions)

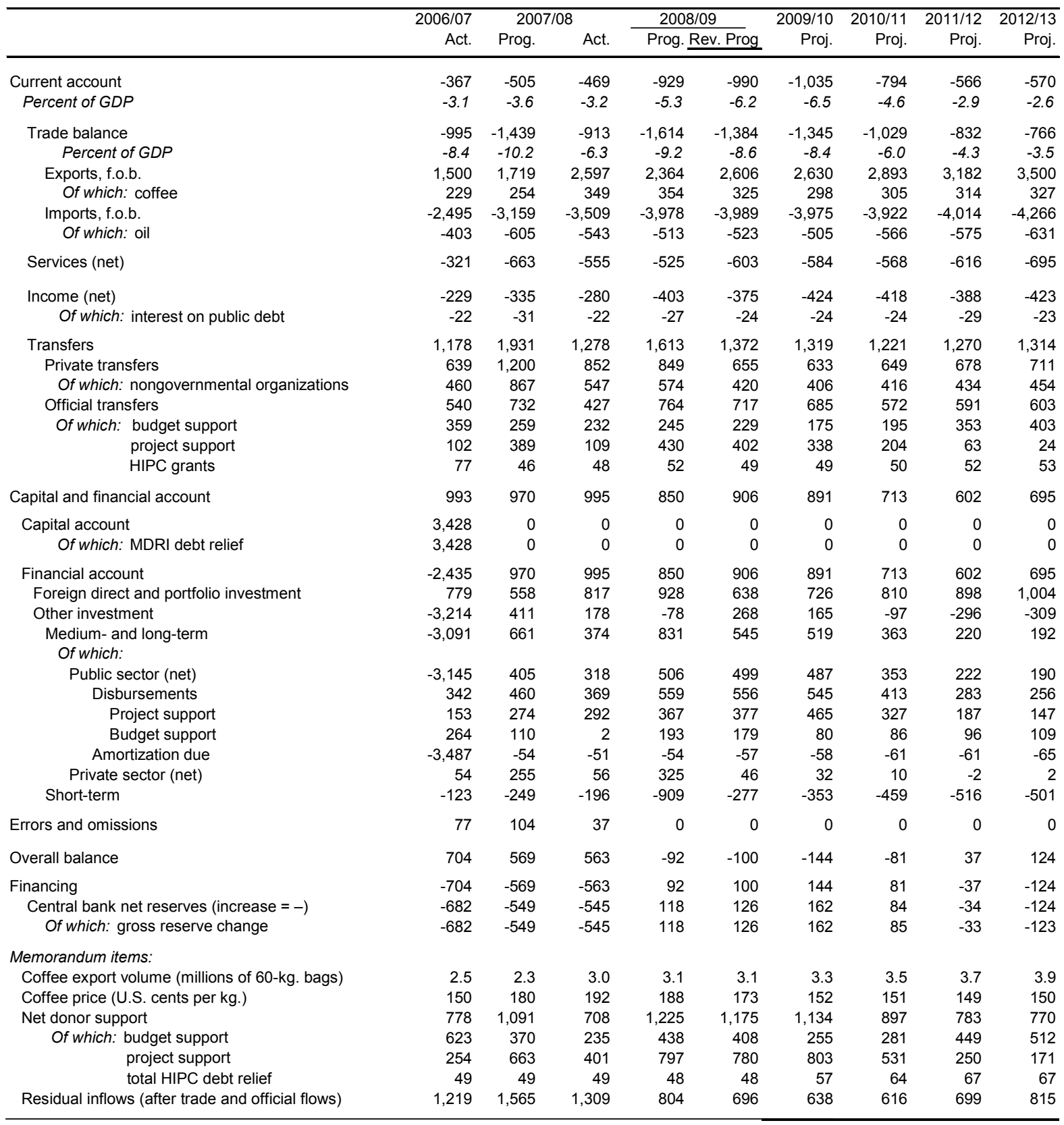

Sources: Ugandan authorities; and IMF staff estimates and projections.

${ }^{1}$ Fiscal year begins on July 1. 


\begin{tabular}{|c|c|c|c|c|c|c|c|c|}
\hline & \multicolumn{4}{|c|}{ Sept. $30,2008^{3}$} & \multicolumn{4}{|c|}{ Dec. 31, 2008} \\
\hline & Prog. & Adj. Prog. & Actual & $\begin{array}{r}\text { Observed }(\sqrt{ }) / \\
\text { Not Observed }(x)\end{array}$ & Prog. & Adj. Prog. & Actual & $\begin{array}{r}\text { Observed }(\sqrt{ }) / \\
\text { Not Observed }(x)\end{array}$ \\
\hline \multicolumn{9}{|l|}{ Assessment criteria } \\
\hline Ceiling on the increase in net domestic assets of the Bank of Uganda ${ }^{4}$ & 100 & 258 & 143 & $\sqrt{ }$ & 399 & 474 & 459 & $\sqrt{ }$ \\
\hline Ceiling on increase in net claims on the central government by the banking system ${ }^{4}$ & 34 & 223 & 54 & $\sqrt{ }$ & 250 & 584 & 420 & $\sqrt{ }$ \\
\hline \multicolumn{9}{|l|}{$\begin{array}{l}\text { Ceiling on new nonconcessional external borrowing with maturities greater than one year contracted } \\
\text { or guaranteed by the government or the Bank of Uganda }\end{array}$} \\
\hline Karuma hydropower plant & 400 & 400 & 0 & $\sqrt{ }$ & 400 & 400 & 0 & $\sqrt{ }$ \\
\hline JBIC loan guarantee to Phenix textile factory & 6 & 6 & 3 & v & 6 & 6 & 3 & $\sqrt{ }$ \\
\hline Other & 0 & 0 & 0 & $\sqrt{ }$ & 0 & 0 & 0 & v \\
\hline \multicolumn{9}{|l|}{ Ceiling on new external debt with maturity up to one year contracted or guaranteed by the } \\
\hline government or the Bank of Uganda 5,7 & 0 & 0 & 0 & $\sqrt{ }$ & 0 & 0 & 0 & $\sqrt{ }$ \\
\hline Minimum increase in net international reserves of the Bank of Uganda & 28 & -66 & 84 & $\sqrt{ }$ & -100 & -147 & -100 & 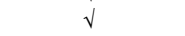 \\
\hline \multicolumn{9}{|l|}{ Indicative targets } \\
\hline Ceiling on increase in base money liabilities of the Bank of Uganda ${ }^{4}$ & 147 & 147 & 98 & $\sqrt{ }$ & 239 & 239 & 299 & $\mathrm{x}$ \\
\hline Stock of domestic budgetary arrears under the Commitment Control System (CCS) ${ }^{8}$ & - & -- & -- & & -- & -- & -- & \\
\hline Minimum expenditures under the Poverty Action Fund (including the Universal Primary & & & & & & & & \\
\hline Education component of development expenditure) & 298 & 298 & 133 & $\mathrm{x}$ & 327 & 327 & 343 & $\sqrt{ }$ \\
\hline
\end{tabular}

${ }^{1}$ The assessment criteria and indicative targets under the program, and their adjusters, are defined in the TMU.

Fiscal year begins on July 1 .

3 Indicative target.

${ }^{4}$ For September and December 2008 cumulative changes from average of June 2008, as defined in the TMU.

${ }^{5}$ Continuous performance criterion.

${ }^{6}$ Continuous performance Criterion.

7 Cumulative change from December 1,2

${ }^{8}$ Excluding normal import-related credits.
Target is only monitored at the end of the fiscal year, i.e. June 2009. 
Table 6. Uganda: Structural Assessment Criterion and Benchmark ${ }^{1}$

\begin{tabular}{|c|c|c|c|c|}
\hline Policy Measure & $\begin{array}{l}\text { Date of } \\
\text { Implementation }\end{array}$ & $\begin{array}{l}\text { Type of } \\
\text { condition }\end{array}$ & $\begin{array}{l}\text { Macro } \\
\text { Criticality }\end{array}$ & $\begin{array}{l}\text { Implementation } \\
\text { Status }\end{array}$ \\
\hline $\begin{array}{l}\text { Implement pilot Integrated Personnel } \\
\text { and Payroll System in three } \\
\text { Commissions (Public Service } \\
\text { Commission, Health Service } \\
\text { Commission, Education Service } \\
\text { Commission), Ministries (Ministry of } \\
\text { Finance, Ministry of Health, Ministry of } \\
\text { Public Service, Ministry of Education), } \\
\text { and Local Governments (Lira and Jinja } \\
\text { Districts). }\end{array}$ & End-July 2009 & $\begin{array}{l}\text { Performance } \\
\text { criterion }\end{array}$ & $\begin{array}{l}\text { To improve } \\
\text { fiscal control } \\
\text { and increase } \\
\text { efficiency in } \\
\text { fiscal } \\
\text { spending }\end{array}$ & $\begin{array}{l}\text { Proposed to be } \\
\text { converted to a } \\
\text { benchmark in line } \\
\text { with recent Board } \\
\text { decision. } \\
\text { Implementation to } \\
\text { be rephased to } \\
\text { November } 30,2009\end{array}$ \\
\hline $\begin{array}{l}\text { Submit to Parliament draft regulatory } \\
\text { framework for pension funds. }\end{array}$ & $\begin{array}{l}\text { End-December } \\
2008\end{array}$ & Benchmark & $\begin{array}{l}\text { To enhance } \\
\text { the stability of } \\
\text { the financial } \\
\text { system and } \\
\text { promote } \\
\text { private } \\
\text { savings. }\end{array}$ & $\begin{array}{l}\text { Not met. Submission } \\
\text { now expected by } \\
\text { September } 30 \text {, } \\
\text { 2009. Proposed as } \\
\text { an end September } \\
2009 \text { structural } \\
\text { benchmark }\end{array}$ \\
\hline
\end{tabular}

${ }^{1}$ Assessment criteria also apply on a continuous basis to the standard provisions on the exchange and trade issues that apply to programs supported by the Fund's financial resources. 
Table 7. Uganda: Financial Soundness Indicator, 2000-2008

(In percent, unless otherwise indicated)

\begin{tabular}{|c|c|c|c|c|c|c|c|c|c|}
\hline & 2000 & 2001 & 2002 & 2003 & 2004 & 2005 & 2006 & 2007 & 2008 \\
\hline \multicolumn{10}{|l|}{ Commercial Banks } \\
\hline Regulatory capital to risk weighted assets & 20.5 & 23.1 & 22.1 & 16.9 & 20.5 & 18.3 & 18.0 & 19.5 & 20.7 \\
\hline Regulatory Tier I capital to risk-weighted assets & 17.4 & 20.5 & 19.4 & 14.4 & 18.7 & 16.8 & 16.5 & 17.8 & 18.7 \\
\hline Nonperforming loans net of loan-loss provision to capital & 11.3 & 5.0 & 1.5 & 5.6 & 0.1 & -0.3 & 2.6 & 4.4 & -1.5 \\
\hline Nonperforming loans to total gross loans & 9.8 & 6.5 & 3.0 & 7.2 & 2.2 & 2.3 & 2.9 & 4.1 & 2.2 \\
\hline Return on assets & 4.8 & 4.5 & 3.0 & 4.5 & 4.3 & 3.6 & 3.4 & 3.9 & 3.5 \\
\hline Return on equity & 59.2 & 45.6 & 30.6 & 43.2 & 37.8 & 29.6 & 28.3 & 31.4 & 25.0 \\
\hline Net interest income to gross income & 51.8 & 54.5 & 53.7 & 58.3 & 53.2 & 55.2 & 82.2 & 81.8 & 51.3 \\
\hline Noninterest expenses to gross income & 30.9 & 29.6 & 35.5 & 28.4 & 35.6 & 32.9 & 30.6 & 33.0 & 53.0 \\
\hline Liquid asset to total assets* & 60.1 & 63.4 & 63.7 & 43.9 & 46.4 & 42.2 & 33.6 & 30.1 & 29.9 \\
\hline Liquid asset to short-term liabilities & 77.1 & 81.8 & 66.2 & 57.7 & 62.1 & 57.6 & 47.1 & 42.4 & 61.3 \\
\hline Net open position in foreign exchange to capital & 11.4 & 4.0 & 4.3 & -2.1 & -1.8 & -2.4 & -6.8 & -7.7 & -1.4 \\
\hline \multicolumn{10}{|l|}{ Sectoral distribution of loans ${ }^{*}$} \\
\hline Manufacturing & 40.0 & 36.5 & 27.6 & 26.2 & 22.4 & 19.1 & 15.9 & 16.7 & 14.2 \\
\hline Trade and Services & 20.4 & 23.1 & 26.1 & 22.6 & 14.9 & 14.6 & 15.6 & 13.5 & 18.2 \\
\hline Energy and Minerals & 0.3 & 0.8 & 0.4 & 0.3 & 0.1 & 0.6 & 0.3 & 0.6 & 0.8 \\
\hline Agriculture & 9.9 & 9.9 & 8.1 & 9.6 & 11.1 & 12.5 & 6.8 & 9.1 & 6.9 \\
\hline Construction and Property & 4.2 & 3.7 & 3.0 & 3.2 & 4.0 & 4.5 & 5.6 & 5.6 & 10.9 \\
\hline Government & 0.5 & 0.3 & 0.5 & 0.3 & 0.1 & 0.1 & 0.1 & 0.0 & 0.1 \\
\hline Other & 24.6 & 25.8 & 34.2 & 37.7 & 47.4 & 48.5 & 55.7 & 54.5 & 48.9 \\
\hline \multicolumn{10}{|l|}{ Other Indicators } \\
\hline Loan-loss provisions to nonperforming loans & 61.7 & 70.0 & 81.5 & 76.5 & 97.8 & 103.8 & 74.4 & 71.8 & 120.3 \\
\hline Total credit (Total Advances)/GDP & 5.6 & 5.1 & 6.1 & 6.6 & 6.9 & 7.7 & 9.1 & 16.0 & n.a. \\
\hline Change in credit to GDP ratio & 10.7 & -7.7 & 18.8 & 9.0 & 4.4 & 11.5 & 18.3 & 6.8 & n.a. \\
\hline Net interest income to average total assets & 8.4 & 8.6 & 6.4 & 8.3 & 8.3 & 8.1 & 11.9 & 12.5 & 8.4 \\
\hline Non interest expenses to average total assets & 6.8 & 7.0 & 6.5 & 6.8 & 7.8 & 7.4 & 7.4 & 7.1 & 8.7 \\
\hline Loans to assets & 28.5 & 25.7 & 26.9 & 28.3 & 29.5 & 34.1 & 38.2 & 38.7 & 45.1 \\
\hline Liquid assets to total deposits & 84.2 & 87.6 & 86.1 & 59.5 & 63.1 & 60.0 & 50.7 & 46.7 & 48.1 \\
\hline Net claims on government to total assets & 10.9 & 18.5 & 31.4 & 32.0 & 32.6 & 21.3 & 18.5 & 22.0 & 20.6 \\
\hline Foreign currency deposits to total deposits & 33.0 & 27.5 & 27.3 & 33.8 & 33.5 & 30.3 & 32.0 & 31.8 & 28.4 \\
\hline
\end{tabular}

The method of computing liquid assets was revised in 2004

Source: Ugandan authorities 
APPENDIX I. Letter of Intent

Kampala, Uganda

May 13, 2009

\author{
Mr. Dominique Strauss Kahn \\ Managing Director \\ International Monetary Fund \\ Washington, D.C. 20431
}

Dear Mr. Strauss Kahn:

On behalf of the Government of Uganda, I would like to inform you of the progress we have made under our economic program backed by the Fund's Policy Support Instrument (PSI) and transmit the attached Memorandum of Economic and Financial policies (MEFP), which sets out the objectives and policies that the Government intends to pursue in the short and medium term. The policies outlined in the MEFP are drawn from the Government's initiatives to promote employment and sustain economic growth in a stable macroeconomic environment.

Reflecting our strong policy implementation, all assessment criteria for the completion of the fifth review have been observed. However, new challenges to macroeconomic stability have emerged; the global financial crisis and slowdown in activity in our major trading partners is weakening our external financing resources and affecting our growth prospects in the near term. Nonetheless, we think we are in a position to absorb the shock without major macroeconomic stress; our banking system remains well capitalized, foreign exchange reserves are at a comfortable position, and providing donor support is disbursed on time, we expect to implement our spending plans as envisaged.

The Government of Uganda believes that the policies set forth in the MEFP are adequate to achieve the objectives of our PSI-supported program. Given our interest in macroeconomic stability, we stand ready to take additional measures as may be necessary to achieve needed objectives. Our PSI proposes modification of assessment criteria for the performance target date of end-June for the sixth review, which is expected to be completed by end December 2009 , and the conversion of the structural assessment criterion on implementation of an integrated personnel and payment system into a structural benchmark. We stand ready to work with the Fund and other development partners in the implementation of our program and will consult in advance should revisions be contemplated to the policies contained in the PSI. 
The Government of Uganda authorizes the publication and distribution of this letter, its attachments, and all reports prepared by Fund staff regarding the current PSI review.

Sincerely yours,

$$
\text { / s / }
$$

Mrs. Syda Bbumba

Minister of Finance, Planning, and Economic Development 


\section{Attachment I. Uganda: Memorandum of Economic and Financial Policies Update}

May 13, 2009

1. The Government of Uganda remains committed to sustained macroeconomic stability, economic growth, and poverty reduction, as set out in the Poverty Eradication Action Plan (PEAP). The Government and the International Monetary Fund (IMF) are cooperating on an economic program to attain these goals through a three-year Policy Support Instrument (PSI). This updated Memorandum of Economic and Financial Policies (MEFP) describes performance under this program through February 2009, sets specific policies and targets through June 2009, and lays out preliminary objectives for the next fiscal year (July 2009-June 2010).

\section{Performance under the PSI}

2. All assessment criteria for December 2008 were met. The submission to parliament of a draft regulatory framework for pension funds - a structural benchmark for end-December - was delayed by the implementation of a broad-based consultation process with the private sector and other important stakeholders. The consultation process has been finalized and submission to Parliament is now expected by September 2009. We ask that the relevant structural benchmark be rephased accordingly.

\section{Objectives and Policies Looking Forward}

3. As the global financial crisis begins to affect the Ugandan economy, our overarching policy objectives remain to ensure high and sustained growth and poverty reduction while preserving macroeconomic and financial stability. Growth in FY2008/09 seems likely to decelerate from the high levels of recent years. Nonetheless, we think that we are still in a position to advance in the implementation of our key infrastructure development projects. This will provide support to the domestic economy and enhance Uganda's long-term growth potential. As the precise extent of the slowdown in Uganda and in the world economy is still subject to a high degree of uncertainty, we are monitoring the situation closely and stand ready to further adjust our policies if circumstances were to warrant it.

\section{A. Fiscal Policy}

4. Both revenue collection and spending execution fell short of our budget targets in the first half of FY2008/09. Revenue collections have been weak, largely on account of slower-than-envisaged economic activity, higher growth in non-dutiable goods than in dutiable ones, and technical, hopefully temporary, disruptions in trade with Kenya. Expenditures were lower due to start-up difficulties in certain government programs, 
particularly in the road sector. Delays in grants disbursements also constrained the execution of some externally-funded projects. Overall, the fiscal deficit was significantly smaller than scheduled.

\section{We have taken significant steps to execute the spending programs as}

appropriated. With stepped-up collection efforts, tax revenue recovered in January and February. Further administrative enhancements (including more frequent use of audits and arrears collections) and higher-than-expected profitability among banks and telecom companies - all major tax payers - should limit the tax revenue shortfall to about 160 billion shillings for the whole fiscal year. Grant disbursements have also picked up in early 2009, and measures have been introduced to accelerate the execution of government projects. In all, we project development spending to increase by somewhat more than 2 percent of GDP, which while short of the initial target will go a long way toward addressing Uganda's infrastructure deficit. The resources earmarked for the road corridor are expected to be used in full during this fiscal year. If, however, absorption were to fall short, these resources will be made available in the following fiscal year (2009/10). Notwithstanding the shortfall in revenues, we expect the fiscal deficit (excluding grants) to be somewhat lower than programmed, as the shortfall in development spending is set to slightly exceed that in revenues.

\section{Next year's budget will aim at pursuing our infrastructure development plans} while being mindful of the possible impact of the global slowdown on domestic and external financing sources. The National Budget Framework Paper (NBFP), recently presented to Parliament, lays out an initial list of priority spending areas (mainly roads, energy and agriculture), together with measures to further increase revenue and spending efficiency. Our initial target is for a somewhat smaller overall deficit than in the current fiscal year, to avoid draining scarce financial resources. In the run-up to the presentation of the final Budget to Parliament on June 11, we will refine and reassess this proposal in line with developments in both the domestic and global economy.

\section{We remain committed to continue strengthening fiscal administration and} oversight. According to the latest information available, new CCS arrears accumulated in FY2007/08 are estimated at Ush 61 billion, compared to Ush 28 billion in FY2006/07. This is a source of concern and we intend to adequately budget for utilities and to implement measures contained in the Debt Strategy in order to avoid future occurrences. More broadly, we remain committed to improve the efficiency of tax collection agencies in Uganda. We are proceeding with several critical reforms in this area, including the creation of the Medium Taxpayers Office, scheduled to start its operation by September 2009.

\section{Progress on the Ministry of Public Service's new Integrated Personnel and}

Payroll System (IPPS) continues. Progress continues with respect to the implementation of the pilot IPPS in selected government agencies and the IPPS phase one is scheduled to go live in the pilot ministries by November 30, 2009. The full rollout will commence in 
July 2010. We propose that, in line with recent changes in IMF policies, the relevant structural assessment criterion be converted into a structural benchmark and we propose to rephase this structural benchmark accordingly.

9. The indicative target on poverty-related spending was met by a comfortable margin, reflecting the government's efforts to increase allocations to programs directly focused at the poorest segments of the population.

\section{B. Monetary and Financial Sector Policies}

10. Monetary policy will ensure that inflation remains on a downward path while providing sufficient liquidity to support a healthy level of economic activity. Following the surge in international fuel and food prices, inflation reached double-digit peaks in mid2008. It has been gradually declining since then, except for a temporary upward blip in prices in early 2009 because of a surge in regional demand for food products and other exogenous factors. In the last quarter of this fiscal year, the Bank of Uganda (BOU) will target an annual reserve money growth rate of about 20 percent, which should contain domestic demand pressures while still allowing for a healthy growth in private sector credit and maintenance of a reserve coverage of about 5 months of imports.

11. Heightened uncertainties in the context of the global financial crisis pose new challenges for monetary policy management, particularly short-term liquidity management. A sudden and unanticipated reversal in portfolio inflows contributed to a depreciation of the currency. Subsequently, delays in government spending and a rising demand for domestic currency had a constraining impact on liquidity, resulting in a sharp increase in interest rates.

12. The BOU intends to develop promptly modalities for a more flexible response to such shocks. While the reserve money program will continue to guide monetary policy implementation, procedures for very short-term liquidity management will be reassessed and estimates of changes in autonomous factors of liquidity refined and better informed by market intelligence. The BOU will develop a periodic review process to assess deviations between short-term liquidity outcomes and medium-term monetary objectives; if it is determined that they carry an inflationary or deflationary risk, the BOU will examine the need for an adjustment in the reserve money path.

13. The international economic slowdown and financial crisis has and will continue to impact adversely Uganda's external accounts. While there is no indication of a decline in official aid, export receipts, private transfers and FDI slowed in the last quarter of 2008 and are expected to remain slow in the near future. Reflecting in part the high import component of our public investment plans, we expect the current and capital account balances of the balance of payments to decline, leading to a small drawdown in reserves. 
We remain committed to let market forces determine the level of the exchange rate, intervening only to smoothen out excessive volatility.

14. While our banks have so far remained sound and stable, we are keenly aware of the risks arising from the financial crisis and are prepared to react swiftly should the need arise. So far, Uganda's financial system has been relatively insulated from the global financial crisis, but a slowing economy and the depreciation of the shilling could raise challenges for banks. To minimize any such risk, we are enhancing our crisis response framework. We are strengthening our infrastructure for liquidity provision and interbank transactions. We are also, in conjunction with regional supervisors, accelerating work on contingency cross-border management arrangements. Among prevention measures, our bank supervision authorities have intensified their oversight of bank practices, requesting them to conduct regular stress-testing of their exposures, monitoring of their foreign placements, and encouraging them to exercise caution in foreign currency lending to unhedged borrowers. 
Attachment I. Table 1. Uganda: Quantitative Assessment Criteria and Indicative Targets for March 2009 - December, $2009^{1}$ (Cumulative change from the beginning of the fiscal year, unless otherwise stated) ${ }^{2}$

\begin{tabular}{|c|c|c|c|c|c|}
\hline & $\begin{array}{l}\text { March } 31 \\
2009^{3} \\
\text { Prog. }\end{array}$ & $\begin{array}{l}\text { June } 30 \\
2009 \\
\text { Prog. }\end{array}$ & $\begin{array}{l}\text { June } 30 \\
2009 \\
\text { Revised }\end{array}$ & $\begin{array}{l}\text { September } 3 C \\
2009^{3} \\
\text { Prog. }\end{array}$ & $\begin{array}{l}2009^{3} \\
\text { Prog. }\end{array}$ \\
\hline Assessment criteria & \multicolumn{5}{|c|}{ (U Sh billions) } \\
\hline Ceiling on the increase in net domestic assets of the Bank of Uganda ${ }^{4}$ & 441 & 478 & 577 & 357 & 486 \\
\hline Ceiling on the increase in net claims on the central government by the banking system ${ }^{4}$ & 130 & 71 & S\$ millions) & 61 & 199 \\
\hline $\begin{array}{l}\text { Ceiling on the stock of external payments arrears incurred by the government or the Bank of Uganda }{ }^{5} \\
\text { Ceiling on new nonconcessional external borrowing with maturities greater than one year contracted } \\
\text { or guaranteed by the government or the Bank of Uganda }\end{array}$ & 0 & 0 & 0 & 0 & 0 \\
\hline Karuma hydropower plant & 400 & 400 & 400 & 400 & 400 \\
\hline JBIC loan guarantee to Phenix textile factory & 6 & 6 & 6 & 6 & 6 \\
\hline $\begin{array}{l}\text { Other } \\
\text { Ceiling on new external debt with maturity up to one year contracted or guaranteed by the }\end{array}$ & 0 & 0 & 0 & 0 & 0 \\
\hline government or the Bank of Uganda ${ }^{5,7}$ & 0 & 0 & 0 & 0 & 0 \\
\hline Minimum increase in net international reserves of the Bank of Uganda & -117 & -117 & -126 & -104 & -115 \\
\hline Indicative target & \multicolumn{5}{|c|}{ (U Sh billions ) } \\
\hline Ceiling on the increase in base money liabilities of the Bank of Uganda ${ }^{4}$ & 254 & 290 & 330 & 153 & 260 \\
\hline Stock of domestic budgetary arrears under the Commitment Control System (CCS) ${ }^{8}$ & $\ldots$ & 81 & 81 & $\ldots$ & $\ldots$ \\
\hline $\begin{array}{l}\text { Minimum expenditures under the Poverty Action Fund (including the Universal Primary } \\
\text { Education component of development expenditure) }\end{array}$ & 496 & 662 & 662 & 80 & 160 \\
\hline
\end{tabular}

${ }^{1}$ The assessment criteria and indicative targets under the program, and their adjusters, are defined in the TMU.

${ }^{2}$ Fiscal year begins on July 1 .

3 Indicative target.

4 For March and June 2009, cumulative changes are from average of June 2008;

for September and December 2009 cumulative changes from average of June 2009, as defined in the TMU.

${ }^{5}$ Continuous performance criterion.

${ }^{6}$ Cumulative change from December 1, 2006.

${ }^{7}$ Excluding normal import-related credits.

${ }^{8}$ Arrears incurred after end-June 2004. Excludes new arrears accumulated during the current fiscal year. 
Table 2. Uganda: Proposed Structural Benchmarks ${ }^{1}$

\section{Structural Benchmarks}

Implement pilot Integrated Personnel and Payroll System in three

End-November 2009

Commissions (Public Service Commission, Health Service

Commission, Education Service Commission), Ministries (Ministry of

Finance, Ministry of Health, Ministry of Public Service, Ministry of

Education), and Local Governments (Lira and Jinja Districts).

Submit to Parliament draft regulatory framework for pension funds.

End-September 2009

${ }^{1}$ Benchmarks also apply on a continuous basis to the standard provisions on the exchange and trade issues that apply to programs supported by the Fund's financial resources. 


\section{Attachment II. Uganda: Technical Memorandum of Understanding}

May 13, 2009

\section{A. Introduction}

1. This memorandum defines the targets described in the memorandum of economic and financial policies (MEFP) for the July 2006-June 2009 financial program supported by the IMF Policy Support Instrument (PSI), and sets forth the reporting requirements under the instrument.

\section{B. Net Foreign Assets (NFA) and Net Domestic Assets (NDA) of the Bank of Uganda (BOU)}

2. The net foreign assets of the BOU are defined as the monthly average (based on daily data) of foreign assets minus foreign liabilities, and include all foreign claims and liabilities of the central bank. The monthly average values of all foreign assets and liabilities will be converted into U.S. dollars at each test date using the average cross exchange rates for December 2008 for the various currencies and then converted into Uganda shillings using the average U.S. dollar-Uganda shilling exchange rate for December 2008.

\begin{tabular}{|l|l|}
\hline \multicolumn{2}{|c|}{ Program Exchange Rates (US\$ per currency unit, unless indicated otherwise) } \\
\hline Euro & 1.36986 \\
\hline British pound & 1.4900 \\
\hline Japanese Yen & 0.01095 \\
\hline Kenya shilling & 0.01281 \\
\hline SDR & 1.53946 \\
\hline Uganda shilling (per US\$1) & 1956.19 \\
\hline
\end{tabular}

Net domestic assets (NDA) of the BOU are defined as the monthly average (based on daily data) of base money (defined below) less net foreign assets of the BOU (as defined in para. 2). Based on this definition, the NDA limits will be cumulative changes from the average of June 2008 to the average of March and June 2009, and cumulative changes from the average of June 2009 to the average of September and December 2009. 


\begin{tabular}{|l|c|c|c|c|}
\hline \multicolumn{5}{|c|}{ (In billions of shillings) } \\
\hline & $\begin{array}{c}\text { March 31, } \\
2009\end{array}$ & June 30, 2009 & $\begin{array}{c}\text { September 30, } \\
2009\end{array}$ & $\begin{array}{c}\text { December 31, } \\
2009\end{array}$ \\
\hline $\begin{array}{l}\text { Cumulative change in } \\
\text { base money }\end{array}$ & 254 & 331 & 153.2 & 260.2 \\
\hline $\begin{array}{l}\text { Cumulative change in } \\
\text { NFA }\end{array}$ & -187 & -246 & -204 & -226 \\
\hline $\begin{array}{l}\text { Cumulative change in } \\
\text { NDA }\end{array}$ & 441 & 577 & 357 & 486 \\
\hline
\end{tabular}

\section{B. Base Money}

3. Base money is defined as the sum of currency issued by the BOU and the commercial banks' deposits in the BOU. The commercial bank deposits include the statutory required reserves and excess reserves held at the BOU and are net of the deposits of closed banks at the BOU and Development Finance Funds (DFF) contributed by commercial banks held at the BOU. The base money limits will be cumulative changes from the daily average of June 2008 to the daily average of March and June 2009, and cumulative changes from the daily average of June 2009 to the daily average of September and December 2009.

\section{Net Claims on the Central Government by the Banking System}

4. Net claims on the central government (NCG) by the banking system is defined as the difference between the outstanding amount of bank credits to the central government and the central government's deposits with the banking system, excluding deposits in administered accounts and project accounts with the banking system, including the central bank. Credits comprise bank loans and advances to the government and holdings of government securities and promissory notes. Central government's deposits with the banking system include the full amount of IMF MDRI. NCG will be calculated based on data from balance sheets of the monetary authority and commercial banks as per the monetary survey. The quarterly limits on the change in NCG by the banking system will be cumulative beginning end-June in the previous fiscal year.

\section{Net International Reserves of the BOU}

5. $\quad$ Net international reserves (NIR) of the BOU are defined for program monitoring purpose as reserve assets of the BOU net of short-term external liabilities of the BOU. Reserve assets are defined as external assets readily available to, and controlled by, the BOU and exclude pledged or otherwise encumbered external assets, including, but not limited to, assets used as collateral or guarantees for third-party liabilities. Short-term 
external liabilities are defined as liabilities to nonresidents, of original maturities less than one year, contracted by the BOU and include outstanding IMF purchases and loans.

6. For program-monitoring purposes, reserve assets and short-term liabilities at the end of each test period will be calculated in U.S. dollars by converting them from their original currency denomination at program exchange rates (as specified in para. 2).

\section{E. Ceiling on Domestic Budgetary Arrears of the Central Government}

7. The stock of domestic payment arrears under the Commitment Controls System (CCS) will be monitored on an annual basis. Domestic payments arrears under the CCS are defined as the sum of all bills that have been received by a central government spending unit or line ministry delivered prior to the beginning of the current fiscal year, and for which payment has not been made within 30 days under the recurrent expenditure budget (excluding court awards) or the development expenditure budget. For the purpose of program monitoring, the quarterly CCS reports, which will include arrears accumulated at IFMS and non-IFMS sites, prepared by the Internal Audit and Inspection Office will be used to monitor arrears. Arrears can be cleared in cash or through debt swaps.

8. The payments of pre-CCS, non-CCS, and CCS arrears accumulated up to end-June 2004 ("group A arrears") are covered by specific budget allocations for 2008/09 and 2009/10. The program ceiling on the stock of CCS arrears only covers accumulation of arrears after end-June 2004 ("group B arrears"). According to the verified report prepared by the Internal Audit and Inspection Office, this stock of arrears is estimated at U Sh 111 billion as of June 2007.

\section{F. Expenditures under the Poverty Action Fund (PAF).}

9. The compliance with the indicative target on minimum expenditures under the PAF will be verified on the basis of releases (PAF resources made available to spending agencies).

\section{G. Adjusters}

10. The NDA and NIR targets are based on program assumptions regarding budget support, assistance provided under the Heavily Indebted Poor Countries (HIPC) Initiative and the Multilateral Debt Relief Initiative (MDRI), and external debt-service payments.

11. The NCG target, in addition to being based on the aforementioned assumptions, is also based on assumptions regarding domestic nonbank financing of central government fiscal operations. In addition, the NDA target depends on the legal reserve requirements on deposits in commercial banks. Finally, the NDA and NIR targets are based on program assumptions regarding automatic access by commercial banks to the BOU's rediscount and discount window facilities. 
12. The Uganda shilling equivalent of budget support (grants and loans) plus HIPC Initiative assistance in the form of grants on a cumulative basis from July 1 of the fiscal year is presented under Schedule A. The ceilings on the cumulative increase in NDA and NCG will be adjusted downward (upward), and the floor on the cumulative increase in NIR of the BOU will be adjusted upward (downward) by the amount by which budget support, grants and loans, plus HIPC Initiative and MDRI assistance, exceeds (falls short of) the projected amounts.

\begin{tabular}{|l|c|c|c|c|}
\hline \multicolumn{5}{|c|}{$\begin{array}{c}\text { Schedule A: Budget Support Plus Total HIPC Initiative Assistance } \\
\text { (Cumulative billions of Uganda shillings, beginning July 1 of the fiscal year) }\end{array}$} \\
\hline Quarter & March 31, 2009 & June 30, 2009 & $\begin{array}{c}\text { September 30, } \\
2009\end{array}$ & $\begin{array}{c}\text { December 31, } \\
2009\end{array}$ \\
\hline $\begin{array}{l}\text { Budget support, including } \\
\text { HIPC Initiative grants }\end{array}$ & 509 & 867 & 120 & 246 \\
\hline
\end{tabular}

13. The ceiling on the increases in NDA and NCG will be adjusted downward (upward) and the floor on the increase in NIR will be adjusted upward (downward) by the amount by which debt service due ${ }^{1}$ plus payments of external debt arrears less deferred payments (exceptional financing) falls short of (exceeds) the projections presented in Schedule B. Deferred payments are defined to be (i) all debt service rescheduled under the HIPC Initiative; and (ii) payments falling due to all non-HIPC Initiative creditors that are not currently being serviced by the authorities (that is, gross new arrears being incurred).

\begin{tabular}{|l|c|c|c|c|}
\hline \multicolumn{5}{|c|}{$\begin{array}{c}\text { Schedule B: Debt Service Due, Before HIPC Initiative Assistance } \\
\text { (Cumulative billions of Uganda shillings, beginning July 1 of the fiscal year) }\end{array}$} \\
\hline Quarter & March 31, 2009 & June 30, 2009 & September 30, 2009 & December 31, 2009 \\
\hline $\begin{array}{l}\text { Debt service due before HIPC, } \\
\text { excluding exceptional } \\
\text { financing }\end{array}$ & 158 & 204 & 17 & 31 \\
\hline
\end{tabular}

14. The ceiling on the increase in NCG will be adjusted downward (upward) by any excess (shortfall) in nonbank financing ${ }^{2}$ less payment of domestic group A arrears relative

\footnotetext{
${ }^{1}$ Debt service due is defined as pre-HIPC Initiative debt service due, but from 2003/04 onwards, this excludes HIPC Initiative debt rescheduling.

${ }^{2}$ Comprising the check float and the change in government securities and government promissory notes held by the nonbank sector. The change in government securities held by the nonbank sector will be calculated from the data provided by the Central Depository System (CDS).
} 
to the programmed cumulative amounts presented in Schedule C. For the purpose of this adjuster, payment of domestic group A arrears cannot exceed the programmed amount by more than U Sh 45.0 billion.

\begin{tabular}{|l|c|c|c|c|}
\hline \multicolumn{5}{|c|}{$\begin{array}{c}\text { Schedule C: Nonbank Financing Minus Repayment of Domestic Arrears } \\
\text { (Cumulative billions of Uganda shillings, beginning July 1 of the fiscal year) }\end{array}$} \\
\hline Quarter & March 31, 2009 & June 30, 2009 & September 30, 2009 & December 31, 2009 \\
\hline $\begin{array}{l}\text { (A) Nonbank } \\
\text { financing }\end{array}$ & 145 & 170 & 18 & 50 \\
\hline $\begin{array}{l}\text { (B) Domestic arrears } \\
\text { repayment }\end{array}$ & 225 & 300 & 11 & 24 \\
\hline (C) Total = (A) -(B) & -80 & -130 & 7 & 26 \\
\hline
\end{tabular}

15. The ceiling on NDA of the BOU for end-June will be adjusted upward by the daily average amount of commercial bank automatic access to the BOU discount window and rediscounting of government securities by commercial banks.

16. The ceiling on NDA of the BOU for every test date will be adjusted downward/upward to reflect decreases/increases in the legal reserve requirements on deposits in commercial banks. The adjuster will be calculated as the percent change in the reserve requirement multiplied by the actual amount of required reserves (Uganda shillings and foreign-currency denominated) at the end of the previous calendar month.

\section{H. External Borrowing Contracted or Guaranteed by the Central Government, Statutory Bodies, or the Bank of Uganda, and Arrears}

17. The assessment criterion on short-term debt refers to contracting or guaranteeing external debt with original maturity of one year or less by the government or the BOU. Excluded from this assessment criterion are normal import-related credits. The definition of "debt" is set out in paragraph 19.

18. The program includes a ceiling on new nonconcessional borrowing with maturities greater than one year contracted or guaranteed by the government, statutory bodies, or the BOU. ${ }^{3}$ Nonconcessional borrowing is defined as loans with a grant element of less than 35 percent, calculated using average commercial interest rates references (CIRRs) published by the Organization for Economic Cooperation and Development (OECD). In assessing the level of concessionality, the 10-year average CIRRs should be used to discount loans with

\footnotetext{
${ }^{3}$ Contraction is defined as approval by a resolution of Parliament as required in Section 20(3) of the Public Finance and Accountability Act, 2003
} 
maturities of at least 15 years, while the 6-month average CIRRs should be used for loans with shorter maturities. To both the 10-year and 6-month averages, the following margins for differing payment periods should be added: 0.75 percent for repayment periods of less than 15 years; 1 percent for $15-19$ years; 1.15 percent for 20-25 years; and 1.25 percent for 30 years or more. The ceiling on nonconcessional external borrowing or guarantees is to be observed on a continuous basis. The coverage of borrowing includes financial leases and other instruments giving rise to external liabilities, contingent or otherwise, on nonconcessional terms. Excluded from the limits are changes in indebtedness resulting from refinancing credits and rescheduling operations, and credits extended by the IMF. For the purposes of the program, arrangements to pay over time obligations arising from judicial awards to external creditors that have not complied with the HIPC Initiative do not constitute nonconcessional external borrowing. For the purposes of the program, the Bujagali project is defined as the hydroelectric dam and related equipment located at the dam site.

19. The definition of debt, for the purposes of the limit, is set out in point 9 of the Guidelines on Performance Criteria with Respect to External Debt (Executive Board's Decision No. 12274-(00/85), August 24, 2000). It not only applies to the debt as defined in Point 9 of the Executive Board decision, but also to commitments contracted or guaranteed for which value has not been received. The definition of debt set forth in No. 9 of the Guidelines on Performance Criteria with Respect to External Debt in Fund Arrangements reads as follows:

(a) For the purpose of this guideline, the term "debt" will be understood to mean a current, i.e., not contingent, liability, created under a contractual arrangement through the provision of value in the form of assets (including currency) or services, and which requires the obligor to make one or more payments in the form of assets (including currency) or services, at some future point(s) in time; these payments will discharge the principal and/or interest liabilities incurred under the contract. Debts can take a number of forms, the primary ones being as follows: (i) loans, i.e., advances of money to the obligor by the lender made on the basis of an undertaking that the obligor will repay the funds in the future (including deposits, bonds, debentures, commercial loans and buyers' credits) and temporary exchanges of assets that are equivalent to fully collateralized loans under which the obligor is required to repay the funds, and usually pay interest, by repurchasing the collateral from the buyer in the future (such as repurchase agreements and official swap arrangements); (ii) suppliers' credits, i.e., contracts where the supplier permits the obligor to defer payments until some time after the date on which the goods are delivered or services are provided; and (iii) leases, i.e., arrangements under which property is provided which the lessee has the right to use for one or more specified period(s) of time that are usually shorter than the total expected service life of the property, while the lesser retains the title to the property. For the purpose of the guideline, the debt is the present value (at the inception of the lease) of all lease 
payments expected to be made during the period of the agreement excluding those payments that cover the operation, repair, or maintenance of the property. (b) Under the definition of debt set out in point 9(a) above, arrears, penalties, and judicially awarded damages arising from the failure to make payment under a contractual obligation that constitutes debt. Failure to make payment on an obligation that is not considered debt under this definition (e.g., payment on delivery) will not give rise to debt.

20. The ceiling on the accumulation of new external payments arrears is zero. This limit, which is to be observed on a continuous basis, applies to the change in the stock of overdue payments on debt contracted or guaranteed by the government, the BOU, and statutory bodies ${ }^{4}$ from their level at end-June 2006 . It comprises those external arrears reported by the Trade and External Debt Department of the BOU, the Macro Department of the Ministry of Finance that cannot be rescheduled because they were disbursed after the Paris Club cutoff date.

\section{Monitoring and Reporting Requirements}

21. The authorities will inform the IMF staff in writing at least ten business days (excluding legal holidays in Uganda or in the United States) prior to making any changes in economic and financial policies that could affect the outcome of the financial program. Such policies include but are not limited to customs and tax laws (including tax rates, exemptions, allowances, and thresholds), wage policy, and financial support to public and private enterprises. The authorities will similarly inform the IMF staff of any nonconcessional external debt contracted or guaranteed by the government, the BOU, or any statutory bodies, and any accumulation of new external payments arrears on the debt contracted or guaranteed by these entities. The authorities will furnish an official communication to the IMF describing program performance of quantitative and structural assessment criteria and benchmarks within 8 weeks of a test date. The authorities will on a regular basis submit information to IMF staff with the frequency and submission time lag as indicated in Table 1. The information should be mailed electronically to AFRUGA@IMF.ORG.

\footnotetext{
${ }^{4}$ This definition is consistent with the coverage of public sector borrowing defined by the Fund (includes the debt of the general government, monetary authorities, and entities that are public corporations which are subject to the control by government units, defined as the ability to determine general corporate policy or by at least 50 percent government ownership).
} 


\section{Table 1. Summary of Reporting Requirements}

\begin{tabular}{|c|c|c|c|}
\hline $\begin{array}{l}\text { Reporting } \\
\text { institution }\end{array}$ & Report/Table & Frequency & $\begin{array}{l}\text { Submission } \\
\text { lag }\end{array}$ \\
\hline \multirow{12}{*}{$\begin{array}{l}\text { I. Bank of } \\
\text { Uganda }\end{array}$} & Issuance of government securities. & Weekly & 5 working days \\
\hline & Interest rates on government securities. & Weekly & 5 working days \\
\hline & $\begin{array}{l}\text { Operations in the foreign exchange market and daily } \\
\text { average exchange rates. }\end{array}$ & Weekly & 5 working days \\
\hline & Consumer price index. & Monthly & 2 weeks \\
\hline & $\begin{array}{l}\text { Balance sheet of the BOU, consolidated accounts of the } \\
\text { commercial banks, and monetary survey. The Internal } \\
\text { Audit Department (IAD) of the BOU will review the } \\
\text { reconciliations of monetary survey data with the financial } \\
\text { records and the audited financial statements. Any } \\
\text { revisions to monetary survey data, in line with the } \\
\text { recommendations of the IMF safeguards mission, will be } \\
\text { documented and reconciled with the previous } \\
\text { presentation to ensure accurate reporting. }\end{array}$ & Monthly & 4 weeks \\
\hline & $\begin{array}{l}\text { Composition of foreign assets and liabilities of the BOU } \\
\text { by currency of denomination. }\end{array}$ & Monthly & 4 weeks \\
\hline & $\begin{array}{l}\text { Statement of (i) cash balances held in project accounts } \\
\text { at commercial banks; (ii) total value (measured at issue } \\
\text { price) of outstanding government securities from the } \\
\text { Central Depository System (CDS); and (iii) the stock of } \\
\text { government securities (measured at issue price) held by } \\
\text { commercial banks from the CDS. }\end{array}$ & Monthly & 6 weeks \\
\hline & $\begin{array}{l}\text { Summary of (i) monthly commodity and direction of } \\
\text { trade statistics; (ii) disbursements, principal and } \\
\text { interest, flows of debt rescheduling and debt } \\
\text { cancellation, arrears, and committed undisbursed } \\
\text { balances-by creditor category; and (iii) composition of } \\
\text { nominal HIPC Initiative assistance, disaggregated into } \\
\text { grants, flow rescheduling, and stock-of-debt reduction } \\
\text { by creditor. }\end{array}$ & Monthly & 6 weeks \\
\hline & $\begin{array}{l}\text { Summary of stock of external debt, external arrears, and } \\
\text { committed undisbursed loan balances by creditor. }\end{array}$ & Quarterly & 6 weeks \\
\hline & $\begin{array}{l}\text { Standard off-site bank supervision indicators for deposit } \\
\text { money banks. }\end{array}$ & Quarterly & 4 weeks \\
\hline & $\begin{array}{l}\text { Summary table of preliminary program performance } \\
\text { comparing actual monthly outcome with adjusted } \\
\text { program targets for (i) base money; (ii) net claims on } \\
\text { central government by the banking system; (iii) stock of } \\
\text { external arrears; (iv) new nonconcessional external } \\
\text { borrowing; and (v) net international reserves }\end{array}$ & Quarterly & 5 weeks \\
\hline & $\begin{array}{l}\text { Daily average amount of commercial bank automatic } \\
\text { access to the BOU discount window and rediscounting } \\
\text { of government securities by commercial banks. }\end{array}$ & Quarterly & 4 weeks \\
\hline
\end{tabular}




\begin{tabular}{|c|c|c|c|}
\hline \multicolumn{4}{|c|}{ Attachment II. Table 1. Summary of Reporting Requirements (concluded) } \\
\hline $\begin{array}{l}\text { Reporting } \\
\text { institution }\end{array}$ & Report/Table & Frequency & $\begin{array}{c}\text { Submission } \\
\text { lag }\end{array}$ \\
\hline & & & \\
\hline \multirow[t]{7}{*}{$\begin{array}{l}\text { II. Ministry of } \\
\text { Finance }\end{array}$} & $\begin{array}{l}\text { Summary of central government accounts. Revenues } \\
\text { shall be recorded on a cash basis. Expenditures shall be } \\
\text { recorded when checks are issued, except for domestic } \\
\text { and external debt-service payments, cash transfers to } \\
\text { districts, and externally funded development } \\
\text { expenditures. Expenditures on domestic interest will be } \\
\text { recorded on an accrual basis and external debt service } \\
\text { will be recorded on a commitment basis (i.e., when } \\
\text { payment is due). Cash transfers to districts will be } \\
\text { recorded as expenditures of the central government } \\
\text { when the transfer is effected by the BOU. Expenditures } \\
\text { on externally funded development programs will be } \\
\text { recorded as the sum of estimated disbursements of } \\
\text { project loans and grants by donors, less the change in } \\
\text { the stock of government project accounts held at the } \\
\text { BOU and domestic commercial banks. }\end{array}$ & Monthly & 6 weeks \\
\hline & $\begin{array}{l}\text { Summary of outstanding stock of group (B) domestic } \\
\text { arrears. Group (B) arrears comprise the stock of } \\
\text { CCS/IFMS arrears incurred after end-June } 2004 \text {. }\end{array}$ & Quarterly & 6 weeks \\
\hline & $\begin{array}{l}\text { Summary of contingent liabilities of the central } \\
\text { government. For the purpose of the program, contingent } \\
\text { liabilities include all borrowings by statutory bodies, } \\
\text { government guarantees, claims against the government } \\
\text { in court cases that are pending, or court awards that the } \\
\text { government has appealed. }\end{array}$ & Quarterly & 6 weeks \\
\hline & $\begin{array}{l}\text { Detailed central government account of disbursed } \\
\text { budget support grants and loans, HIPC support, and } \\
\text { external debt service due and paid. }\end{array}$ & Monthly & 4 weeks \\
\hline & $\begin{array}{l}\text { Detailed central government account of disbursed donor } \\
\text { project support grants and loans. }\end{array}$ & Monthly & 6 weeks \\
\hline & $\begin{array}{l}\text { Statement on new loans contracted during the period } \\
\text { according to loan agreements. }\end{array}$ & Quarterly & 6 weeks \\
\hline & $\begin{array}{l}\text { Updated national accounts statistics (real and nominal) } \\
\text { according to UBOS and medium-term projections. }\end{array}$ & Quarterly & 4 weeks \\
\hline
\end{tabular}




\section{INTERNATIONAL MONETARY FUND}

UGANDA

Fifth Review Under the Policy Support Instrument-Informational Annex

Prepared by the African Department

(In consultation with other departments)

May 13, 2009

- $\quad$ Relations with the Fund. Describes financial and technical assistance by the IMF and provides information on the safeguards assessment and exchange system. Outstanding Fund credit was SDR 6 million (3.3 percent of quota) at end-March, 2009.

- Joint Bank-Fund Work Program. Describes Bank-Fund collaboration through December 2009. 


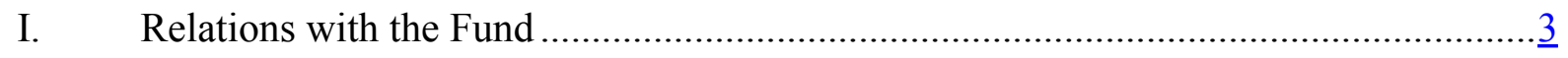

II. Joint Bank-Fund Work Program............................................................................ 
APPENDiX I. UGANDA: RELATIONS WITH THE FUND

(As of March 31, 2009)

I. Membership Status: Joined: September 27, 1963;

$\underline{\text { Article VIII }}$

II. General Resources Account:

SDR Million

\%Quota

Quota

180.50

100.00

Fund holdings of currency

180.51

100.00

III. SDR Department:

SDR Million

\%Allocation

Net cumulative allocation

29.40

100.00

$\underline{\text { Holdings }}$

0.06

0.20

IV. Outstanding Purchases and Loans:

PRGF Arrangements

SDR Million

\%Quota

6.00

\section{Latest Financial Arrangements:}

\begin{tabular}{|c|c|c|c|c|}
\hline Type & $\begin{array}{c}\text { Date of } \\
\text { Arrangement }\end{array}$ & $\begin{array}{c}\text { Expiration } \\
\text { Date }\end{array}$ & $\begin{array}{c}\text { Amount Approved } \\
\text { (SDR Million) }\end{array}$ & $\begin{array}{l}\text { Amount Drawn } \\
\text { (SDR Million) }\end{array}$ \\
\hline PRGF & Sep 13,2002 & $\operatorname{Jan} 31 \overline{, 2006}$ & 13.50 & 13.50 \\
\hline ESAF/PRGF & Nov 10,1997 & Mar 31, 2001 & 100.43 & 100.43 \\
\hline ESAF & Sep 06, 1994 & Nov 09, 1997 & 120.51 & 120.51 \\
\hline
\end{tabular}

\section{Projected Payments to Fund}

(SDR Million; based on existing use of resources and present holdings of SDRs):

Forthcoming

Principal

\begin{tabular}{|c|c|c|c|c|}
\hline 2009 & 2010 & 2011 & 2012 & 2013 \\
\hline & 0.20 & 1.00 & 1.20 & 1.20 \\
\hline 0.13 & 0.15 & 0.15 & 0.15 & 0.14 \\
\hline$\underline{0.13}$ & $\underline{0.35}$ & $\underline{1.15}$ & $\underline{1.35}$ & $\underline{1.34}$ \\
\hline
\end{tabular}


VII. Implementation of HIPC Initiative:

I. Commitment of HIPC assistance

Original Enhanced

Decision point date

Framework Framework

$\underline{\text { Total }}$

Apr 1997 Feb 2000

Assistance committed

by all creditors (US\$ Million) ${ }^{1 /}$

347.00

656.00

Of which: IMF assistance (US\$ million)

68.90

91.00

(SDR equivalent in millions)

51.51

68.10

Completion point date

Apr 1998 May 2000

II. Disbursement of IMF assistance (SDR Million)

Assistance disbursed to the member

51.51

Interim assistance

Completion point balance

Additional disbursement of interest income ${ }^{2 /}$
Total disbursements

$\begin{array}{rr}-- & 8.20 \\ 51.51 & 59.90 \\ -- & 2.06\end{array}$

51.51
70.16
119.61

2.06

121.67

\section{Implementation of Multilateral Debt Relief Initiative (MDRI):}

I. MDRI-eligible debt (SDR Million) $)^{3 /}$

87.73

Financed by: MDRI Trust

Remaining HIPC resources

II. Debt Relief by Facility (SDR Million)

Eligible Debt

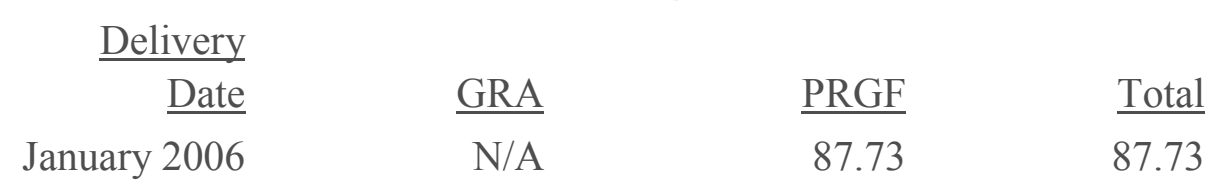

\footnotetext{
${ }^{1 /}$ Assistance committed under the original framework is expressed in net present value (NPV) terms at the completion point, and assistance committed under the enhanced framework is expressed in NPV terms at the decision point. Hence these two amounts can not be added.

${ }^{2 /}$ Under the enhanced framework, an additional disbursement is made at the completion point corresponding to interest income earned on the amount committed at the decision point but not disbursed during the interim period.

${ }^{3 /}$ The MDRI provides 100 percent debt relief to eligible member countries that qualified for the assistance. Grant assistance from the MDRI Trust and HIPC resources provide debt relief to cover the full stock of debt owed to the Fund as of end-2004 that remains outstanding at the time the member qualifies for such debt relief.
} 


\section{Safeguards Assessments}

Under the Fund's safeguards policy, assessments with respect to the PSI are voluntary. An update assessment of the Bank of Uganda (BOU) was completed on April 10, 2007 and concluded that the BOU had strengthened its safeguards framework since the 2003 assessment. The main developments included implementation of International Financial Reporting Standards, publication of financial statements, establishment of an audit committee, and strengthening of the internal audit function. Staff made recommendations to address remaining vulnerabilities in the legal and internal control areas.

\section{Exchange Rate Arrangement}

The official exchange rate is determined on the interbank market for foreign exchange. As of March 31, 2009, the official exchange rate was U Sh 2051.55 per U.S. dollar. The exchange system is free of restrictions on the making of payments and transfers for current international transactions. Uganda's exchange rate regime is classified as floating.

\section{Article IV Consultation}

The Executive Board concluded the last Article IV consultation on January 7, 2009. The next Article IV consultation with Uganda will be held on the 24-month cycle, subject to the provisions of the decision on consultation cycles approved on July 15, 2002.

In February and April 2001, joint World Bank/Fund missions visited Kampala as part of the Financial Sector Assessment Program (FSAP). A final report was provided to the authorities in November 2001, and an MFD mission discussed the report with the authorities during the Article IV consultation discussion in November 2002; the Financial System Stability Assessment was prepared for Board discussion in February 2003. In November 2004, a joint World Bank/Fund missions visited Kampala for a FSAP update.

\section{Policy Support Instrument (PSI)}

Uganda initiated a 16-month PSI with the Fund in January 2006. The 16-month PSI was replaced by a new three-year PSI in December 2006.

\section{Technical Assistance}

Uganda has received extensive technical assistance from the Fund in recent years. ${ }^{1}$

\footnotetext{
${ }^{1}$ For a description of technical assistance provided prior to 1998, see the staff report for Uganda's request for a three-year arrangement under the PRGF (Country Report 02/213).
} 
An FAD mission visited Kampala in April 1998 to advise the authorities on public service pension reform issues, and another mission visited Kampala in September 1998 to assist the authorities in improving customs administration procedures. A resident advisor in the area of local government budgeting began a six-month assignment in August 1998, which was subsequently extended to October 1999. An FAD resident advisor on budgeting and commitment control commenced a six-month assignment in November 1998, which was extended until June 2002. In October 2000, an FAD mission visited Kampala to provide technical assistance in tax policy and administration. A joint Bank/Fund TA mission visited Kampala in October 2003 to help harmonize tax investment incentives among the member countries of the EAC. An FAD TA mission on tax administration also visited Uganda in October 2004 to develop a comprehensive reform plan for the Uganda Revenue Authority (URA), followed by visits in April 2005 and April - May 2006. Two FAD resident advisors (coordinated through AFRITAC-East) assisted the implementation of a CCS at the local government level and the Fiscal Decentralization Strategy between June 2004 and February 2005. In the upcoming joint FAD-WB mission, the FAD will be represented by AFRITAC East, which would follow up on the recommendations of the 2005 FAD arrears mission and check whether the new financial and physical reporting system for local governments has been implemented. Two FAD resident advisors (coordinated through AFRITAC-East) assisted in the implementation of a Commitment Control Strategy (CCS) at the local government level and the Fiscal Decentralization Strategy between June 2004 and February 2005. FAD has also provided TA in the areas of revenue administration and oil revenue management with three missions from headquarters visiting Kampala during 2008. FAD — represented by three public financial management (PFM) advisors and one revenue administration advisor at AFRITAC East - continues to provide follow-up TA in several fiscal areas, such as cash management; the design of a comprehensive donor-supported PFM reform strategy; and revenue collection enhancements.

A STA multisector statistics mission visited Kampala in December 1998 to conduct a comprehensive assessment of Uganda's macroeconomic statistics, including data compilation and dissemination, and to provide recommendations for improvements. Follow-up STA missions in national accounts and money and banking statistics visited Kampala in MarchApril 2000 to examine the status of implementation of the previous recommendations. A STA mission on government financial statistics (GFS) visited Uganda in December 2001 to assist authorities in improving fiscal reporting by establishing regular reporting systems that are aligned with the GFS Manual 2001, as well as ensuring consistency within monetary sector data for the government. A follow-up mission on GFS visited Uganda in May 2003. A mission visited Uganda during February-March 2002 to review balance of payment statistics and the progress in implementing the recommendations of the multisector mission of 1998 and of the national accounts mission of 2000 with respect to the measurement of goods imports. A follow-up mission on balance of payments statistics visited Uganda in August 2003. Uganda is participating in the General Data Dissemination System (GDDS) and its metadata were 
initially posted on the Fund's Dissemination Standards Bulletin Board in May 2000. A STA mission was in Uganda during February 2005 to prepare a data ROSC.

Since the 2001 FSAP, MFD's TA to Uganda has focused on liquidity management, exchange rate intervention, central bank accounting and auditing, and banking supervision. The authorities have effectively used TA advice on these topics, and they have made good use of an MFD resident advisor, who took up her initial appointment in mid-July 2001. The advisor was fully integrated into the supervision function and has been involved in all aspects of the work, including participating in on-site examinations; she has subsequently been replaced by a second resident advisor. MFD has fielded two TA missions (July 2001 and January 2002) to assist the authorities with liquidity management and address the problems of interest rate volatility and exchange rate interventions. The BOU has started implementing the recommendations made in the report, and now clearly separates sterilization operations and liquidity management; however, they are still having problems with interest rate and exchange rate volatility and have requested follow-up TA in this area. In March and SeptemberOctober 2002, MFD provided TA to improve central bank accounting and the Bank of Uganda's accounting manual. A TA evaluation visit was conducted in June 2003, and an MFD mission following up on monetary and exchange rate operations, public debt, and liquidity management was conducted in March 2004. An FSAP update mission was conducted in November 2004 and focused on access, outreach, and stability issues, which also updated progress made since the last FSAP. A TA mission on enhancing the effectiveness of monetary policy implementation and developing financial markets was conducted in August 2005; in April $2006 \mathrm{MCM}$ and the BOU held a joint workshop on financial market development. In 2008 and 2009 MCM has provided TA to build capacity to undertake financial stability analysis and reporting; and more recently MCM has provided TA in the monetary operations area.

\section{Future Technical Assistance Priorities}

The priorities for Fund technical assistance in the next few years will be in the areas of tax administration, public expenditure management, especially control and monitoring of public arrears at both central and local government levels, monetary and exchange rate management, bank supervision, national accounts statistics, reporting standards for government finance statistics, monetary and balance of payments statistical reporting, central bank accounting, and audit and debt management.

\section{Resident Representative}

The Fund has maintained a resident representative in Uganda since July 1982. 
Appendix II. Joint BAnK-Fund Work Program, JANuARY-December 2009

\begin{tabular}{|c|c|c|c|}
\hline Title & Products & $\begin{array}{l}\text { Provisional } \\
\text { timing of } \\
\text { missions (if } \\
\text { relevant) }\end{array}$ & $\begin{array}{l}\text { Expected } \\
\text { delivery } \\
\text { date }\end{array}$ \\
\hline \multicolumn{4}{|c|}{ A. Mutual information on relevant work programs } \\
\hline \multirow[t]{7}{*}{$\begin{array}{l}\text { Key elements of } \\
\text { World Bank } \\
\text { work program in } \\
\text { next } 12 \text { months }\end{array}$} & $\begin{array}{l}\text { Poverty Reduction Support Credit to enhance } \\
\text { effectiveness of service delivery, public } \\
\text { sector management, and human development } \\
\text { issues. }\end{array}$ & & March 2010 \\
\hline & $\begin{array}{l}\text { The work program will continue to } \\
\text { concentrate on areas within the existing } \\
\text { portfolio, including infrastructure } \\
\text { development (transport and energy), local } \\
\text { government service delivery, agricultural } \\
\text { research and training, Kampala infrastructure } \\
\text { development, and local government service } \\
\text { delivery (including Northern Uganda } \\
\text { rehabilitation). In addition, the Bank plans } \\
\text { support for agricultural technology and } \\
\text { advisory services, Northern Uganda social } \\
\text { protection, roads development, secondary } \\
\text { education, health infrastructure development } \\
\text { minerals development and environment. }\end{array}$ & & June 2009 \\
\hline & $\begin{array}{l}\text { Public Expenditure Review with the focus on } \\
\text { health sector and public sector wages that has } \\
\text { been delivered to client will be disseminated } \\
\text { to wider stakeholders. } \\
\text { PER on roads will be initiated. }\end{array}$ & & June 2009 \\
\hline & Study on fostering financial deepening & & June 2009 \\
\hline & $\begin{array}{l}\text { Strategy paper for GOU's negotiation of the } \\
\text { recommendations of the study } \\
\text { "Understanding and Elimination of Non- } \\
\text { tariff barriers to support Trade Integration } \\
\text { with the EAC" with other member states }\end{array}$ & & June 2009 \\
\hline & $\begin{array}{l}\text { Assessment of the impact of the global crisis } \\
\text { on the Uganda economy }\end{array}$ & & June 2009 \\
\hline & $\begin{array}{l}\text { Dissemination of finding on analytical work } \\
\text { on shared growth in Uganda(Poverty and } \\
\text { Inequality, Labour market dynamics, etc) }\end{array}$ & & June 2009 \\
\hline \multirow{3}{*}{$\begin{array}{l}\text { IMF work } \\
\text { program in next } \\
12 \text { months }\end{array}$} & Fifth Review under PSI & Mar-Apr. 2009 & May 2009 \\
\hline & Staff visit on the government budget & May 2009 & June 2009 \\
\hline & Sixth Review under PSI & September 2009 & Dec. 2009 \\
\hline
\end{tabular}




\begin{tabular}{|c|c|c|c|}
\hline \multicolumn{4}{|c|}{ B. Requests for work program inputs } \\
\hline \multirow{2}{*}{$\begin{array}{l}\text { Fund request to } \\
\text { Bank }\end{array}$} & & & \\
\hline & $\begin{array}{l}\text { 1. Finalize the update of the broad } \\
\text { strategic priorities in the PFM area } \\
\text { (FINMAP) and get agreement with } \\
\text { authorities on next steps. } \\
\text { 2. Update of civil service reform agenda. }\end{array}$ & & Jun 2009 \\
\hline $\begin{array}{l}\text { Bank request to } \\
\text { Fund }\end{array}$ & $\begin{array}{l}\text { 1. Continue to monitor the causes of } \\
\text { changes in the stock and composition of } \\
\text { domestic arrears, feeding advice on } \\
\text { remedies (including through IFMS) into } \\
\text { the FINMAP update. }\end{array}$ & & Ongoing \\
\hline \multicolumn{4}{|c|}{ C. Agreement on joint products and missions } \\
\hline \multirow{2}{*}{$\begin{array}{l}\text { Joint products } \\
\text { in next } 12 \\
\text { months }\end{array}$} & 1. Collaborate on the Joint DSA & Sep.-Oct. 2009 & Dec. 2009 \\
\hline & $\begin{array}{l}\text { 2. Collaborate on the JSAN on the } \\
\text { NDP(new PRSP) when it is completed }\end{array}$ & June-Sep 2009 & Sep 2009 \\
\hline
\end{tabular}


Press Release No. 09/198

International Monetary Fund

FOR IMMEDIATE RELEASE

Washington, D.C. 20431 USA

June 4, 2009

\section{IMF Executive Board Completes Fifth Review Under the Policy Support Instrument for Uganda}

The Executive Board of the International Monetary Fund (IMF) has completed the fifth review under a three-year Policy Support Instrument (PSI) for Uganda following a mission by Fund staff to Kampala in March and April 2009. The Executive Board's decision was taken on a lapse of time basis. 1

After several years of high growth and strong macroeconomic performance, the global financial crisis is now constraining economic activity in Uganda. Growth is expected to slow to 5-6 percent from $91 / 2$ percent over the past three years. Despite these pressures all assessment criteria for the PSI review, including ceilings relating to government debt, were met. The banking system remains sound and well capitalized, and strong fundamentals and continued prudent macroeconomic policies should enable Uganda's economy to absorb the slowdown in growth without major macroeconomic stress.

Uganda's PSI was approved on December 15, 2006 (see Press Release No. 06/281). The program goals include macroeconomic stability, sustainable economic growth, poverty reduction, financial sector deepening, and improved public sector financial management.

The IMF's framework for PSIs is designed for low-income countries that may not need IMF financial assistance, but still seek close cooperation with the IMF in preparation and endorsement of their policy frameworks. PSI-supported programs are based on country-owned poverty reduction strategies adopted in a participatory process involving civil society and development partners. This is intended to ensure that PSI-supported programs are consistent with a comprehensive framework for macroeconomic, structural and social policies to foster growth and reduce poverty. Members' performance under a PSI is reviewed semi-annually, irrespective of the status of the program (see Public Information Notice No. 05/145).

1 The Executive Board takes decisions under its lapse of time procedure when it is agreed by the Board that a proposal can be considered without convening formal discussions. 